Int. J. Dev. Biol. 53: 1427-1443 (2009)

doi: $10.1387 /$ ijdb.072409jp

\title{
Building the vertebrate heart - an evolutionary approach to cardiac development
}

\author{
JOSÉ M. PÉREZ-POMARES, JUAN M. GONZÁLEZ-ROSA and RAMÓN MUÑOZ-CHÁPULI* \\ Department of Animal Biology, Faculty of Science, University of Málaga, Spain
}

\begin{abstract}
The vertebrate heart is unique among the blood pumps described in metazoans. In contrast to the myoepithelial tubes found in most animal phyla, the vertebrate heart is made up of multilayered myocardial cells surrounded by connective tissue derived from epicardium and endocardium, and endowed with complex valvular, coronary vessel and conduction systems. Despite these profound differences, a common genetic program seems to underlie the specification and differentiation of all the cardiac tissues. In this article, we will review the similarities in the transcriptional networks and signalling mechanisms regulating cardiac development in different animals, as well as the origin of the main differences existing between vertebrate and invertebrate hearts. We will pay special attention to the hypotheses concerning the evolutionary origin of the endothelium and the epicardium from ancestral blood cells and pronephric progenitors, respectively. We can summarize the transition between the invertebrate and the vertebrate heart as the result of the thickening of the primarily myoepithelial cardiac tube which was concomitant with: 1) an inner lining by an endothelium with the ability to transform into mesenchyme; 2 ) an outer lining derived from an ancestral pronephric glomerular primordium with vasculogenic potential; 3) a neural crest cell population which reaches the heart from the pharyngeal region; 4) the incorporation of new myocardium at both ends from a second heart field and 5) the formation of specialized chambers. The complex interactions between all these elements originated an exceptionally powerful blood pump which allowed vertebrates to reach their characteristically large size and activity.
\end{abstract}

KEY WORDS: myocardium, epicardium, endocardium, coelom, coronary vessels, cardiac evolution

\section{Introduction}

Hearts, considered in a broad anatomical and functional sense as single, specialized blood-pumping organs localized in the midline of the organism, are found in many animal taxa, including those phylogenetically closer to vertebrates (for a detailed description and evolutionary analysis see Xavier-Neto et al., 2007). Notwithstanding, the vertebrate heart is unique in the Animal Kingdom. The large volume of striated muscle surrounded by connective tissue, the multichambered structure with complex valvular systems between chambers, the presence of epicardium, endocardium, coronary vessels and conduction system and, especially, its high mechanical performance, place the vertebrate heart very far away from all the other blood-pumping organs from Metazoans. These unique features, however, should not lead us to consider the vertebrate heart as a "phylogenetically isolated" organ lacking of an evolutionary history. Common devel- opmental blueprints for the determination of the cardiac progenitors in different animal phyla have been revealed in the last two decades by the advances in the knowledge of gene expression patterns. NK homeodomain proteins, Hand, GATA and T-Box transcription factors are involved in cardiac specification in vertebrates as well as in insects, while BMP and FGF signals are required for cardiac induction in both cases (Zaffran and Frasch, 2002). Finally, the main anatomical difference which is usually

\footnotetext{
Abbreviations used in this paper: APD, anterior pharyngeal domain; AVC, atrioventricular cushion; BL, basal lamina; CC, conal cushions; CE, coelomic epithelium; CO, coelomic cavity; DT, digestive tract; EMT, epithelialmesenchymal transition; EPDC, epicardially-derived cell; HF, heart field; HS, hemal system; IJ, intercellular junction; LA, left atrium; LV, left ventricle; MEC, myoepithelial cell; $\mathrm{PE}$, proepicardial cell; PHF, primary heart field; PPD, posterior pronephric domain; RA, right atrium; RV, right ventricle; SHF, second heart field; VSMC, visceral smooth muscle cell.
}

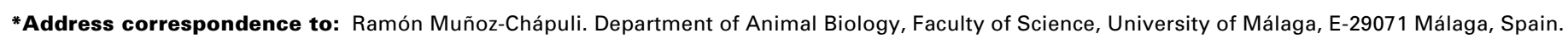
Fax: 34-952-131-668. e-mail: chapuli@uma.es

Final author-corrected PDF published online: 23 January 2009. 

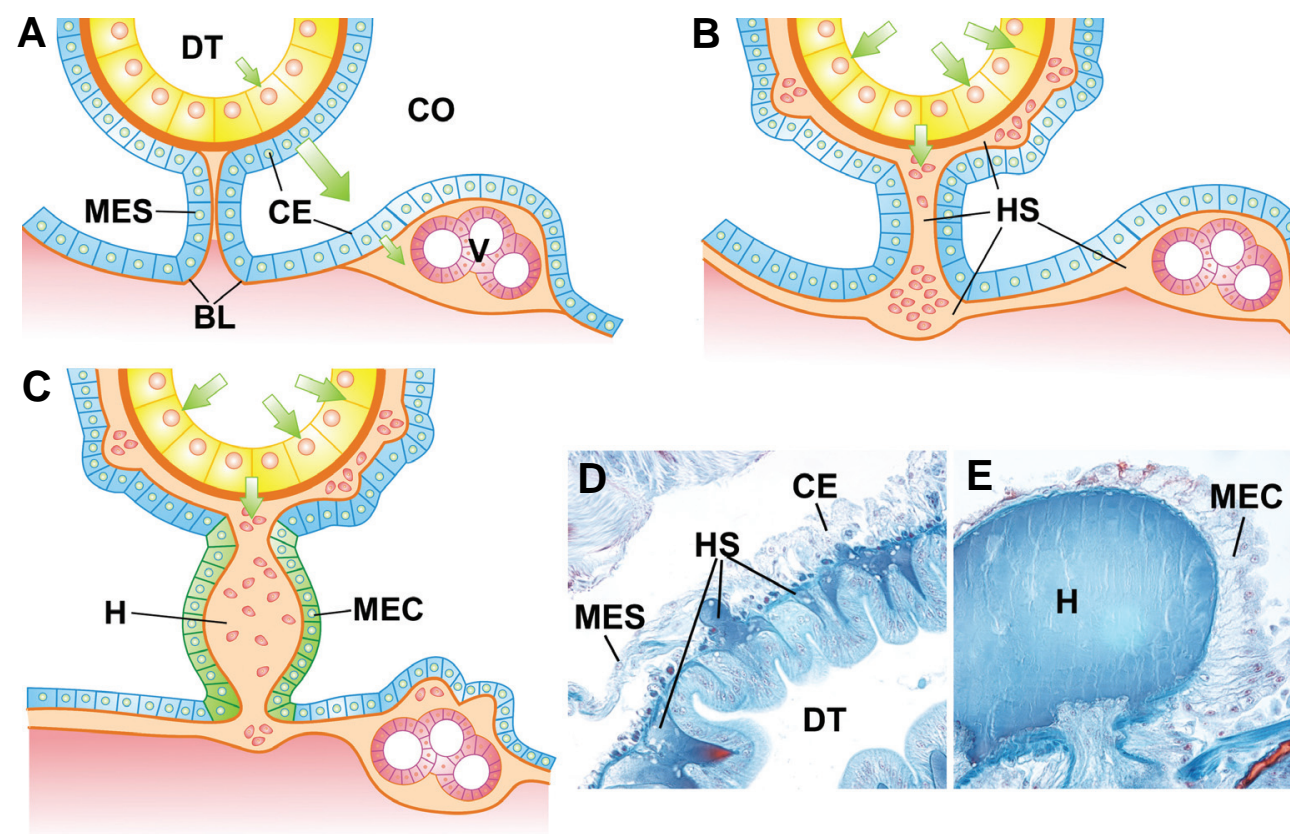

Fig. 1. Development of the hemal system and evolutionary origin of the heart. (A) In coelomate animals, the nutrients (green arrows) absorbed through the digestive tract (DT) arrive to the coelomic cavity (CO), from where they reach the viscerae (V). In this way, the nutrients have to cross twice the coelomic epithelium (CE). (B) The hemal system (in light orange, HS) developed from a network of spaces between the basal laminae (in dark orange, $B L$ ) of the gut epithelium (in yellow) and the coelomic epithelium, and also between the basal laminae of the mesenteries (MES). In this way, the nutrients are conveyed directly to the viscerae surrounded by hemal spaces. (C) The heart $(H)$ arose from transformation of the mesenteric coelomic epithelia into myoepithelial cells (MEC), which acquired contractile abilities and pumped the hemal fluid (i.e. the blood) between the digestive tract and the viscerae. (D) The hemal system (HS) can be observed stained in dark blue in this oligochaete annelid (Lumbricus) between the epithelium of the digestive tract (DT) and the coelomic epithelium (CE). (E) The heart (H) of the same specimen is an enlarged dorsal vessel surrounded by myoepithelial cells (MEC).

claimed between the hearts from protostomes (annelids, arthropods, molluscs) and the vertebrate (deuterostome) heart, i.e. a dorsal and ventral localization, respectively, has been effaced by new concepts in developmental biology as it is now known that the dorsoventral axis has shifted in these organisms, a radical change probably related to the development of a novel mouth in deuterostomes. Thus, all the metazoan hearts share not only a common gene expression basis, but also a defined topological localization (Lowe et al., 2006; Gerhart, 2006).

The existence of great morphological differences among metazoan hearts together with a hypothetical common origin for these organs (grounded both on comparative and molecular evidences) drives us to a question which will constitute the leitmotiv of this review: How did these differences arise in evolution? Or, put in other words, how was the vertebrate heart built? Surprisingly, this evolutionary approach to the origin of the features of the vertebrate heart is missing in the specialized literature, which has specifically focused on the shared genetic programs displayed during cardiogenesis (Holland et al., 2003; Liu et al., 2006; Olson, 2006, Srivastava et al., 2006) or on the evolution of the heart withinvertebrates (Moorman and Christoffels, 2003). Exceptions to be mentioned are two excellent reviews by Simões-Costa et al. (2005) and Xavier-Neto et al. (2007), where the origin of the chambered heart in vertebrates and the issue of the homology of the animal pumping organs are discussed, respectively. We can also quote the studies on the heart of the urochordate Ciona, including an interesting discussion on the origin of some of the evolutionary novelties leading to the vertebrate heart (Davidson and Levine, 2003; Davidson, 2007). It is the main aim of this review to further develop this point of view, based on comparative anatomical and developmental data. In order to do so we will also elaborate on some of our recent work on cardiac development, especially the new models that try to answer some of the hitherto unexplained features of the vertebrate heart, such as the pres- ence of three tissue layers (endocardium, myocardium, epicardium) instead of the single myoepithelial-like cell layer found in the majority of invertebrate hearts.

Before starting with other considerations we would like to comment on the term "invertebrates" which we will use throughout this article. We are aware that "invertebrates" cannot be considered a monophyletic group, and for this reason we are not intending to use the term with a taxonomic meaning. However, the purpose of this review is, as stated above, to account for the origin of the differences between the vertebrate heart and all the other blood-pumping organs which have been described in the metazoans. Thus, we will use "invertebrates", for sake of simplicity, when referring to a set of animal taxa excluding the vertebrates.

\section{The vertebrate heart is unique among Metazoans}

As we have stated above, the vertebrate heart is a chambered organ, constituted by a multilayered myocardium lined externally and internally by epicardium and endocardium, respectively. This heart is thus very different to all the other blood-pumping organs found in metazoans (differences are summarized in Table I; see also Xavier-Neto et al., 2007). Within invertebrates we also find a high degree of variability in their hearts, as we will briefly describe in this chapter.

Due to the extensive genetic, developmental and morphological studies performed in Drosophila, the insect heart is a wellknown structure. In Drosophila, the heart is the only vascular structure that remains in the adult. It consists of a single, posteriorly blind tube of contractile cells located in the dorsal midline and surrounded by "pericardial cells". The function of these cells is probably excretory, and they should not be confused with a true pericardium. During relaxation, hemolymph enters the heart through orifices, and it is pumped to the anterior part of the body by contractions originated in the posterior end (Bodmer and 
Frasch, 1999). The phylogenetically advanced condition of the Drosophila heart is demonstrated by comparison with crustaceans. Heart in decapods is constituted of a single-chambered sac located into a pericardial chamber (Martin and Hose, 1992). The cardiac wall is composed of several layers of striated muscle, externally covered by a coelomic epithelium. Muscular valves have been described in some species (McMahon, 2001).

Annelids also show a patent heart constituted by a dorsal vessel composed of a myoepithelium which is able of peristaltic contractions (Jamieson, 1992). Blood is received from posterior vessels and is pumped in an anterior direction (Figure 1E).

The most complex hearts in invertebrates are found in the molluscs, and more specifically in the cephalopods (Budelmann et al., 1997), which are the biggest invertebrates known. Cephalopod hearts are multichambered, constituted by two atria (four in Nautilus) and a single ventricle. Valves composed of muscular tissue are located between the atria and the ventricle. The atria are formed by 1-2 layers of striated muscle cells surrounded by a collagen-rich matrix. The ventricle is thick, trabeculated, with up to 45 layers of striated muscle cells. This myocardium is covered by a coelomic epithelium (named "epicardium" by analogy). There is no endocardium in these hearts, although the thick basal lamina which is in contact with the blood frequently shows attached circulatory cells (amoebocytes, see below). Myocardial cells are supplied either by the blood circulating through the intertrabecular spaces or by a marginal sinus comprised between the outer myocardial layer and the coelomic epithelium. Octopods lack of marginal sinus and blood microvessels have been described in the surface of the heart. This is the only reported case of a structure similar to coronary vessels in invertebrates, although these vessels lack of endothelium as described below.

Hearts in deuterostomes, with the exception of vertebrates, are far less developed. Echinoderms actually lack of a heart. The axial organ, an enlarged blood vessel constituted of myoepithelial cells, has been claimed to be a pumping organ for the hemal fluid, but many other vessels of these animals are also contractile and contribute to the circulatory function (Chia and Koss, 1994; Smiley, 1994). Hemichordates show contractile dorsal and ventral median vessels, derived from the mesenteria. Additionally, a "heart vesicle" has been described in the hemichordate proboscis (an elongated anterior appendage characteristic of this taxon). This structure is a sac constituted by the coelomic epithelium which surrounds the central blood sinus of the head and com- presses it against the stomochord (an anterior diverticulum of the mouth cavity, formerly regarded as a notochord-related structure) (Benito and Pardos, 1997). The heart vesicle is associated to a glomerulus, a labyrinth of blood sinuses lined by podocytes, which are coelomic cells with a filtering function. The metabolic waste filtered from the blood is released to the coelom of the proboscis and finally evacuated outside the body through a pair of coelomic pores. Stomochord, heart vesicle and glomerulus constituted the so-called preoral heart-kidney or proboscis complex of hemichordates.

Urochordates show a tubular heart composed of a single layered myoepithelium surrounded by a pericardial cavity, the only coelomic cavity of the adult. Pericardium and myoepithelium derive from the same coelomic vesicle which invaginates in the embryo. The heart is V-shaped in Ciona, and shows striated myofilaments (Davidson, 2007). The cardiac myoepithelium pumps the blood, changing the direction of pumping every few minutes due to the alternating predominance of a pair of myogenic pacemakers placed at the ends of the tube (Burighel and Cloney, 1997). Instead, Cephalochordates do not show a definite heart, although the progenitors of a midventral-subintestinal vessel, constituted of a simple myoepithelial tube, expresses AmphiNk2tin, a gene similar to the NK2 class of vertebrates (Holland et al., 2003). However, blood circulation is caused by pulsation of the walls of many vessels, including the afferent pharyngeal arteries (Ruppert, 1997).

\section{A common coelomic origin for animal hearts}

Despite the large differences between the metazoan hearts, summarized in the previous section, all of them share a common involvement of the coelomic epithelium in their development. The heart can simply be a fold of this epithelium, whose cells develop myofibrils and contract, pumping the blood through the hemal spaces (myoepithelial heart), or it can be, as it happens in vertebrates, a complex pump formed by multiple layers of striated muscle. But even in this case, the earliest stages of the cardiac development are characterized by the presence of a cardiac tube continuous with the coelomic epithelium. In order to discuss this close cardiac/coelomic relationship we need to briefly describe first the nature and origin of the circulatory system in the metazoans.

The exchange of nutrients, waste or disolved gasses in acoe-

TABLE 1

\section{COMPARISON OF VERTEBRATE AND INVERTEBRATE HEARTS}

Invertebrates Vertebrates

\begin{tabular}{|c|c|c|}
\hline & Invertebrates & Vertebrates \\
\hline Chambers & $\begin{array}{l}\text { Usually one (except cephalopods), derived from a single cardiogenic field as far } \\
\text { as it known }\end{array}$ & Originally four, arising from a primary and a secondary cardiogenic field \\
\hline Working cells & $\begin{array}{l}\text { Usually a myoepithelium, sometimes a few layers of striated muscle cells (up to } \\
45 \text { in cephalopods) }\end{array}$ & Multilayered striated myocardium \\
\hline Origin of contraction & Neurogenic or autonomous & Autonomous (intrinsic myogenic pacemaker) \\
\hline Conduction system & Always absent except for the myogenic pacemakers & Present at least in Tetrapods \\
\hline Endocardium & Always absent & Always present \\
\hline Valves & Sometimes present, but always derived from the muscular walls of the heart & $\begin{array}{l}\text { Always present, derived from myocardium (sinoatrial), or with leaflets derived from the } \\
\text { endocardium, with contribution of other populations (epicardially derived cells, neural crest) }\end{array}$ \\
\hline Epicardium & $\begin{array}{l}\text { In some groups a coelomic epithelium invests the heart but it does not supply } \\
\text { cells to the cardiac wall }\end{array}$ & $\begin{array}{l}\text { Always present, and originated from an extracardiac primordium. It gives rise to cardiac } \\
\text { vessels and connective tissue }\end{array}$ \\
\hline Vascularization & Luminal blood flow. Some "capillaries" lacking of endothelium in cephalopods & Coronary cardiac vessels, well developed except for small fish and some amphibians \\
\hline
\end{tabular}


lomate animals (cnidarians, ctenophores, platyhelminthes) occurs by diffusion throughout the intercellular medium. Fluid-filled cavities of the so-called "pseucoelomates" and specially the coelomic cavities of the coelomates, lined by a mesodermal epithelium, were the first structures which allowed for a better diffusion of these substances (Figure 1A). We are aware that coeloms probably appeared through different mechanisms in protostomozoans and deuterostomozoans, and it is possible that many "pseudocoelomate" taxa derive from coelomate ancestors that have lost the coelomic lining (Wallace et al., 1996). Anyway, the existence of a cavity around the gut and the main viscerae, irrespectively of its origin, contributed to the supply of nutrients to the organs and allowed for larger body sizes.

The hemal or circulatory system probably originated in coelomate animals from the opening of spaces between the basal laminae of the endodermal and coelomic epithelia (Ruppert and Carle, 1983; this is known as the "R\&C model"). These spaces progressed between the coelomic epithelia which are juxtaposed forming the mesenteries. The expansion of this network of fluidfilled spaces, lined by the basal laminae from different epithelia, reached and surrounded most viscerae giving rise to the vessels of the hemal system (Figure 1B-D). It is important to emphasize that invertebrate vessels are always lined by basal laminae (i.e. extracellular matrix). In some groups, coelomic myoepithelial cells acquired occasionally the ability to grow into other tissues thus forming microvessels in non-visceral areas. This is the case of the vascularization of the mollusc mantle, which could in this way become a high-performance locomotory organ. It is important to remark the differences between this "invertebrate angiogenesis" and the typical angiogenic process of vertebrates, since the latter is a result of the activity of the endothelial cells whereas invertebrate microvessels are composed only of myoepithelial cells.

The primitive hemal systems, established between endodermal and mesodermal basal laminae, had two advantages respect to the coelomic circulation of nutrients. First, they were closer to the endodermal epithelium and thus to the nutrients absorbed through the gut, which reach the hemal space before than the coelomic cavity. Second, and probably most important, the hemal spaces are originally lined by the visceral layer of the coelomic epithelium, that frequently undergoes myoepithelial differentiation or it even gives rise to perintestinal smooth muscle. The evolutionary transition from coelomic epithelium towards a myoepithelium and a visceral smooth muscle has been described by Ruppert (Ruppert, 1991; Figure 2). The contractile ability of the visceral coelomic epithelium or their derived cells was soon used to pump the hemal fluid (i.e. the blood) and to actively drive the nutrients towards the viscerae. The evolutionary origin of the heart can be regarded as the specialization of a precise area of the myoepithelium covering the hemal spaces for blood pumping from the gut towards the anterior part of the body and the head (Figure 1C, E). Coelomic cavities never developed a similar pumping system. However, hemal and coelomic cavities have "competed" for being the main circulatory systems in some metazoan phyla. In nemerteans, for example, the well-developed circulatory system, which was once thought to be exceptional in an acoelomate group, is now reinterpreted as a system of coelomic channels which acts as a circulatory system (Turbeville, 1986). In arrhynchobdellid hirudineans (leeches) a system of coelomic channels is extended throughout the body and share with the hemal system the circulatory function (Fernández et al., 1992). The ambulacral system of echinoderms is another instance of well developed coelomic system of channels that, in this case, becomes specialized in locomotion and food capture being the nutrient supply function assumed by the hemal system.

In summary, the origin of the heart in metazoans can be regarded as linked to the network of hemal cavities primarily organized between the basal laminae of the endoderm and the contractile visceral coelomic epithelium. The primitive heart is, basically, a fold of the dorsal (protostomes) or ventral (deuterostomes) coelomic myoepithelium enclosing the hemal cavity and its contractile ability can be traced back in this way to the intestinal peristaltic mechanisms.

\section{Heart fields and the making of a heart}

The vertebrate heart is mainly composed of mesodermal tissues. These tissues originate once gastrulation is initiated with the ingression of cells from the epiblast (Tam and Beddington, 1987, 1992). Although different fate-mapping studies (including direct cell tagging and tracing as well as sophisticated genetic clonal analyses) have shown that a main part of the cells in the early primitive streak have unrestricted differentiation potency (Schoenwolf and Álvarez, 1991; Tam and Zhou, 1996; García-Martínez et al., 1997; Tam and Schoenwolf, 1999). It is also clear that a certain regionalization of tissues closely follows the appearance of the mesoderm and that many

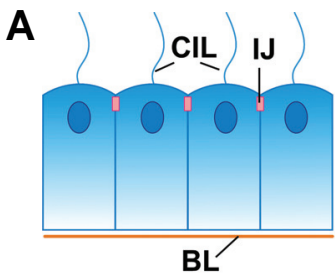

B
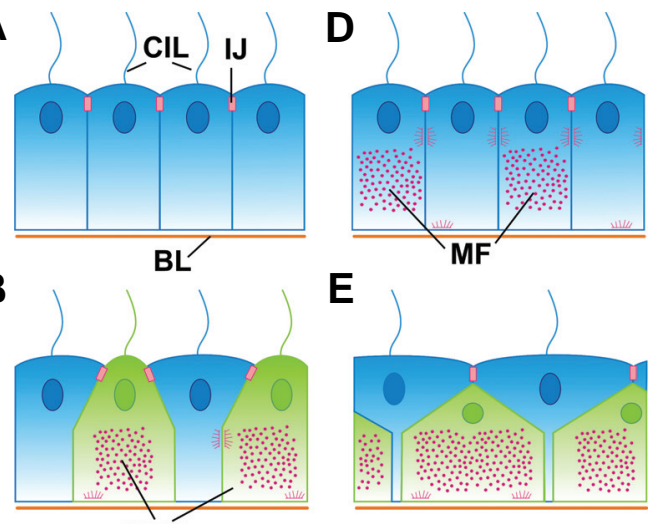

E

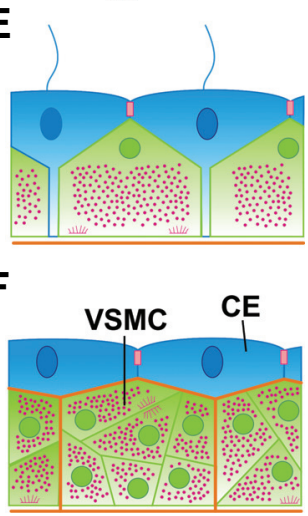

Fig. 2. Model of the evolutionary origin of myoepithelial cells and visceral smooth muscle. Redrawn from Ruppert (1991). (A) Original coelomic cells show cilia (CIL), intercellular junctions (IJ) and a basal lamina (BL). (B) A subset of coelomic cells develop myofilaments, acquiring contractile ability. (C,D) Myofilament-containing contractile cells become myoepithelial cells and relocate most of their cytoplasm towards the basal side, giving rise a pseudostratified epithelium. (E,F) Myoepithelial cells become visceral smooth muscle (VSMC) covered by a typical coelomic epithelium (CE). 
positional cues are determinant in conferring specific developmental competences to distinct cell populations. The cell precursors of the primary vertebrate heart tube originate during early-mid gastrulation. From their original midline primitive streak location they move anterolaterally as a dense mass of mesodermal mesenchyme to form the classic heart field(s) (HFs). The exact distribution of this tissue is still under debate, and many of the discrepancies seem to originate in the differences found in between different animal models. The precardiac mesoderm is often described as a cardiac crescent (horseshoeshaped area) located cranially to the prechordal plate that extends from the right to the left side crossing the midline from very early on (Rosenquist, 1970). This is still accepted to be the case of the mammalian HFs, but recent studies suggest that avian and amphibian embryos have two HFs (left and right) that remain separated for a significant period of time (Colas et al., 2000; Collop et al., 2006). Some authors decided to consider the left and right HF populations as two independent fields (Kirby, 2002) but for the sake of simplicity we will consider them as only one. In any case, the "crescent" concept is linked to the expression domains of some genes (see below).

The bilateral heart fields initiate their differentiation into the endocardial and myocardial lineages while moving to the midline due to the forces generated by the closure of the anterior intestinal portal and the general folding of the embryo. Thus, heart progenitors converge medially to give rise to a single cardiac tube, being the process faster in mouse than in chick embryos (Abu-Issa et al., 2004). Most interestingly, the fusion of a paired primordia is an event also reported for the Drosophila heart (Bodmer, 1990; Bodmer et al., 1993), revealing an ancestral characteristic of early heart-organ development in Metazoans.

The idea that HFs can be fully characterized by their early expression of transcription factors like Nkx2.5, GATA4, SRF and MEF2c (Croissant et al., 1996; Evans, 1999; Black and Olson, 1998) is well extended. Two of these molecules, SRF and Nkx2.5 provide important information relevant to the phylogenetic twist of this review. First, the characteristic SRF expression of the HFs evidences the well known fact that the transcriptional networks that regulate myocardial and smooth muscle differentiation have common elements that are not included in the regulation program of the skeletal striated muscle; this would suggest that, from an evolutionary point of view, smooth muscle and myocardium are closely related. Then, Nkx2.5 expression in the cardiac fields has opened a discussion to define whether the topographical location of precardiac mesoderm absolutely overlaps with the domain of some these so-called "molecular markers" of HFs. In this respect, an elegant work by Redkar and collaborators (2001) has shown that Nkx2.5 may not define the boundaries of the precardiac mesoderm during critical stages of avian development (see Eisenberg, 2000 for a full discussion on the subject). Nkx2.5 is also known to be expressed in anterior endodermal cell populations (Schultheiss et al., 1995), and such finding, irrespectively of the mesodermal specification role associated to this transcription factor, is relevant to this review. Early endodermal expression of $N k \times 2.5$ should be emphasized in here because this gene could be partially regulating the endodermal-mesodermal interaction known to initiate certain mus- cular developmental programs (Lough and Sugi, 2004). From the comparative point of view it is interesting to remark that an Nk2-class gene closely related to $N k \times 2.5, \mathrm{Ceh}-22$, is expressed in myogenic pharyngeal cells of the nematode Caenorhabditis, a worm which lacks of any blood pump. In fact, induced expression of zebrafish Nkx2.5 in Caenorhabditis activates expression of Myo-2, a gene that switches on the myogenic program in these cells. (Okkema and Fire, 1994; Haun et al., 1998). This suggests that the ancestral role of Nkx2.5 (before to be recruited for the cardiac specification program) was probably related with the visceral myogenic program.

The linear cardiac tube was thought to contain all the components of the adult heart that would later on develop into distinct elements of the mature organ (Davis, 1927). The concept has survived until recent times (Srivastava and Olson, 2000) but the enormous advance of our knowledge on how heart develops has changed this vision of heart morphogenesis along the last 5 years (Moorman and Christoffels, 2003; Christoffels et al., 2004; Moorman et al., 2004). It is now accepted that the straight heart tube only contains the outlines of the left ventricle and part of the atrioventricular (AV) region and atrial regions, and therefore the classic precardiac populations (HFs) have been renamed as first or primary heart field (PHFs). To complete the embryonic cardiac outline, myocardial precursors are added to both the arterial (anterior) and venous (posterior) heart poles. The experimental evidence supporting this relevant aspect of cardiac development (Stalsberg and de Haan, 1969; Viragh and Challice, 1973; Argüello et al., 1975) has been overlooked for years and it has only been quite recently accepted that some pre-eminent components of the heart like the right ventricle derive, in both mammals and avians, from an alternative source of cardiac precursors (Kelly et al., 2001; Rana et al., 2007). The exact location of these "new" progenitors at different stages of embryonic development are also controversial, and different terms like "anterior heart field" (AHF), "secondary heart field" and "second heart field" (SHF) have been used to dub this cell population (Kelly et al., 2001; Mjaatvedt et al., 2001; Waldo et al., 2001, 2005; Abu-Issa and Kirby, 2007; Kirby, 2007). The early indiscriminate use of the three terms has created controversy, but a certain consensus has been now met in considering "anterior" and "secondary" heart fields as subpopulations of the "second" heart field (Buckingham et al., 2005; Abu-Issa and Kirby, 2007). However, it has been pointed out that such confusion could also originate in the differences between the animal models and the tracing techniques used in those studies (Kirby, 2007). The "second heart field" is thus defined by molecular (Isl1 expression) and spatio-temporal criteria (mainly based on "clonal" or "retrospective clonal" analyses, Meilhac et al., 2004; Buckingham et al., 2005). Aspects related to "heart fields" are illustrated in Figure 3.

This conceptual frame is apparently supported by the characteristic second heart field (SHF) expression of some molecules like the LIM homeodomain transcription factor /s/et1 (Isl1) (Cai et al., 2003; Laugwitz et al., 2005) but since Isl1 has also been reported to be expressed in part of the PHFs (Yuan and Schoenwolf, 2000; Prall et al., 2007) it is not clear anymore that this transcription factor should be considered as SHFspecific. As a matter of fact, SHF prospective myocardial 
A

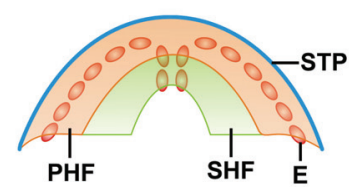

B

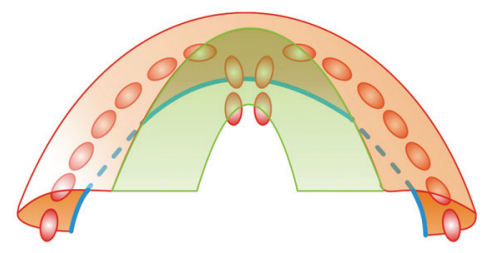

C
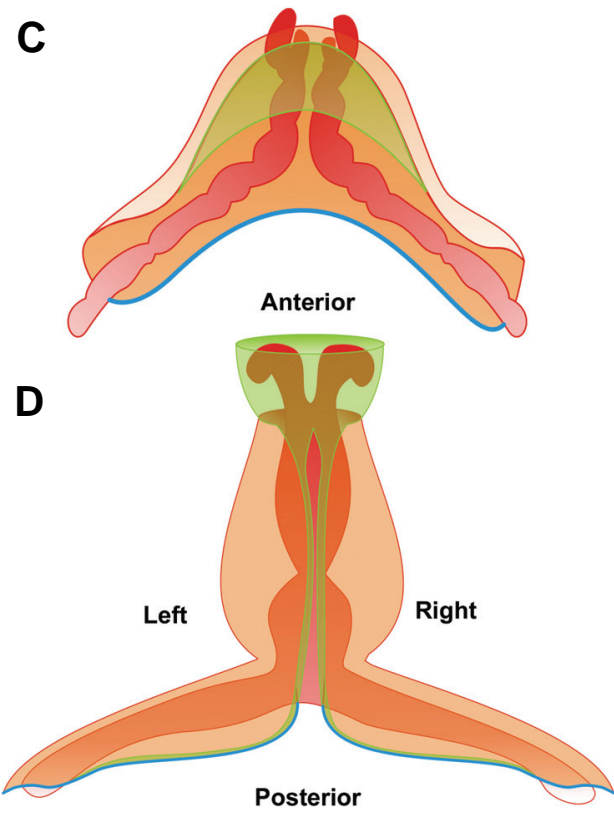

$\mathbf{A}^{\prime}$

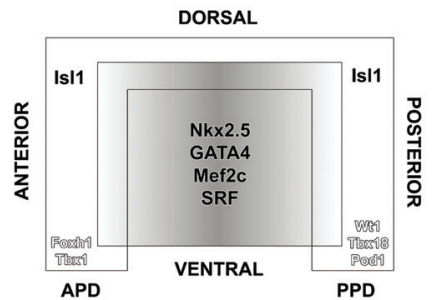

E

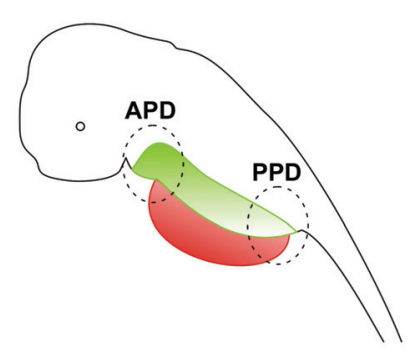

$\mathbf{F}$

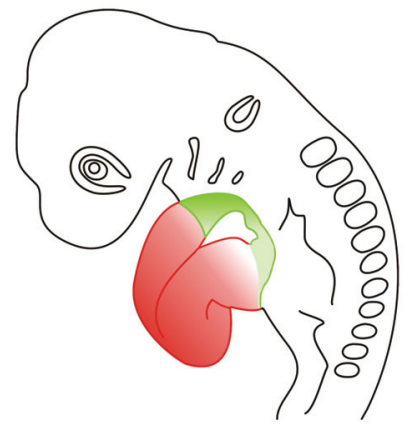

Fig. 3. Cardiac progenitors and heart fields. The drawings represent an ideal vertebrate embryo (not the specific case of the chick or the mouse), and therefore the location of the heart fields is based on an anatomical consensus. The spatial distribution of the different cardiac populations in a cardiac crescent is shown together with the changes affecting to such groups of cells as development proceeds. (A') A simplified diagram representing the domains of the primary heart field (PHF, shadowed central area characterized by the expression of Nkx2.5, GATA4, Mef2c and SRF) and the second heart field (SHF, white inverted-U domain characterized by Is/1 expression) in the forming heart. The expression of characteristic anterior and posterior markers (in white, Tbx 1 , Foxh1, Wt1, Tbx18, Pod1) may be interpreted as a consequence of the overlapping of myocardial precursors with other non-muscular mesenchymal populations with inherent strong signalling properties (anterior pharyngeal domain or APD and posterior pronephric domain or PPD, arrows). (AD) The PHF is coloured in orange, the SHF in green, the endocardium in red (E) and the progenitors of the septum transversum area (STP) are presented by a blue line. All the cartoons display a dorsal view as indicated in (D). The illustrations in $(\mathbf{E}, \mathbf{F})(e m-$ bryos in a left lateral view placed next to the proper crescent stages) help to understand the relative position of the PHF and SHF in the context of the whole embryo; specifically in (E) the mesenchymal anterior pharyngeal (APD) and the posterior pronephric domains (PPD) are shown overlapping with the arterial and venous poles of the heart, respectively. For more details, please refer to the text. potential seems to be, at a certain point, regulated by a set of transcription factors similar to that expressed in the PHF (e.g. Nkx2.5, GATA4 and MEF2c). These transcription factors seem to be expressed under the induction of growth factors of the BMP and FGF families, as it is also known to occur in the PHF (Buckingham et al., 2005). Therefore, although the expression of some SHF-specific molecules like Foxh1 have been recently described (von Both et al., 2004) and the PHF expresses genes which are not characteristic of the SHF (Hand1, Tbx5), the main differences between the two fields are likely to be dependent on the differential regulation of a similar transcriptional network.

We would like to suggest that the SHF transcriptional program seems to be complex likely because of the overlapping domains of the SHF and both an anterior "pharyngeal" mesenchymal domain and a posterior "pronephric" one (see Figure 3). This program has been hypothesized to include Foxh1 a gene that would act as a coordinator of FGF8 and 10 inductive activities over a population of progenitors expressing Isl1 and Tbx1 (Buckingham et al., 2005) that could then activate a basic pan-myocardial set of transcription factors including GATA4 and Mef2c. Mutations in these genes can lead to a complete distortion of the development of the arterial pole of the heart as it happens to be the case with Tbx1 deficiencies, which are closely related to DiGeorge syndrome (Baldini, 2005). GATA factors play essential roles in heart specification in vertebrates and invertebrates, by cooperation with $\mathrm{Nkx2.5/Tinman} \mathrm{and}$ BMP/Dpp signals to induce the expression of cardiac-specific genes such as Hand (Han and Olson, 2005). In Drosophila the expression of the GATA factor pannier is regulated by the Nkx2.5 orthologue tinman, and the pannier protein interacts with tinman activating, in a synergic way, downstream cardiac genes (Gajewski et al., 2001).

The spatial relocation of the SHF as precardiac progenitors change from a $2 D$ to a $3 D$ conformation has been beautifully shown by Moorman and colleagues (2004). This review clearly illustrates the positional relevance of SHF cells as contributors to the development of the heart inflow, a complex area that has recently tempted some cardiovascular developmental biologists to think about the existence of a "third" posterior heart field (Gittenberger de-Groot et al., 2007). In our opinion, this reflects the real complexity of the region rather than a developmental reality (see the discussion below and Figure 3 for more details). In the context of this review, the differences between the most anterior (outflow) and posterior (inflow) subdomains of the SHF 
would be related to the topological domains where each cell population resides ("pharyngeal" and "pronephric", respectively) rather than to intrinsic differences between SHF subpopulations, as we would like to suggest that the interaction between SHF and non-cardiac mesoderm is critical to define and modulate its final developmental fate.

Our novel proposal of an "ancestral pronephric" domain associated to the most posterior (outflow) SHF progenitors (see below for more details) is derived from our studies on cardiac development in lampreys, representatives from the most primitive living vertebrate lineage (Pombal et al., 2008). These studies have shown that the posterior pole of the heart of primitive vertebrates is closely related to the pronephros, and not to the liver, as it happens in gnathostomes (jawed vertebrates). We will develop this point in the section devoted to the development of the epicardium. This ancestral pronephric domain in which the posterior SHF is located accounts for the expression in the venous pole cells of the transcription factors Tbx18 and Wt1, critically involved in kidney development and also in the morphogenesis of the heart inflow (Airik et al., 2006; Christoffels et al., 2006). The expression of other kidneyrelated genes (e.g. podoplanin) has also been described in the posterior SHF (Gittenberger de-Groot et al., 2007).

What about considering cardiac fields from an evolutionary perspective? It would be easy to argue that the SHF is a sort of outcome of the physiological needs generated in the water-toland transition (Moorman et al., 2007). This is, however, a contentious hypothesis, because the cellular contributions of the PHF and the SHF to the pulmonary or systemic heart domains overlap in space. It has also been proposed that the two myocardial lineages (PHF and SHF) may already pre-exist in vertebrate ancestors (Meilhac et al., 2004), a suggestion that seems further supported by with the possible homology between the two lineages of the zebrafish heart muscle (atrial and ventricular; see Keegan et al., 2004) and PHF and SHF. Finally, it could also be argued that the SHF formed by incorporation of a given mass of originally non-heart specified mesoderm (Schoenebeck et al., 2007).

Although the presence of more than one "heart field" has not been reported, it is tempting to relate the secondary heart field with the presence of anterior and posterior growth zones at the ends of the developing heart tube of the urochordate Ciona. In these cardiac areas cells proliferate and differentiate, adding myoepithelial cells to the cardiac wall and allowing for longitudinal growth of the heart. This growth process seems to be active all along the organism lifespan (Millar, 1953, Davidson, 2007) and it is reminiscent of the embryonic recruitment of mesodermal cells to the cardiac lineage in vertebrates. On the other hand, and perhaps more significantly, the existence of potential for a "posterior" SHF has also been experimentally illustrated in Ciona, where the extension of the cardiac tube is regulated by FGF signaling (Davidson et al., 2006). Progenitors of the cardiac tube in Cionaexpress Mesp, a bHLH transcription factor whose vertebrate orthologues Mesp1 and 2 are required for the development of the heart (Kitajima et al., 2000). However, from the Mesp expressing progenitors in Ciona, only a half will contribute to the heart, being the rest specified to anterior tail muscle cells. When the expression of the transcription factor Ets $1 / 2$ is forced in Mesp-expressing cells, all of them form heart, and this extended heart shows sometimes a twocompartment structure that work in synchrony to pump blood. This surprising result shows how originally non-cardiogenic areas of the posterior pole of the heart (i.e. the ancestor of the "posterior" SHF) could be recruited to form a two-chambered heart as a transitional step towards the more complex heart of vertebrates (Davidson, 2007).

\section{Myocardial origin and diversity}

Myocardial cells are believed to form once endocardial progenitors delaminate from the polarized epithelium (Peng et al., 1990) that forms the visceral layer of the lateral plate mesoderm. This is in close contact with the pharyngeal endoderm, a tissue that has been reported to be critical to cardiac muscle development (Lough and Sugi, 1995, 2000).

The significance of myocardial diversity is obvious since the adult heart will require different muscle types to sustain its coordinated pumping function. A primary distinction can be made in between the working myocardium of the developing chambers and the remnants of the primitive myocardium, which are progressively confined to the inflow tract, the AV region and in general the inner curvature of the original heart tube. In this respect, true hearts (considered from a histomorphological perspective) can be defined as "chambered pumps containing inflow and outflow segments invested at some point in an animal's lifetime with myocytes" (Simões-Costa et al., 2005). The definition of cardiac chambers is controversial itself and largely based in the animal model considered, as it is not clear that apparent embryonic cardiac compartments in certain vertebrates can be really considered as chambers (e.g. the sinus venosus or the outflow tract in the mouse as compared with that of sharks). Furthermore, the consideration of hearts as composed by inflow and outflow compartments has its reflection not only in the original anatomical arrangement of the two domains (dorsal versus ventral, respectively) but also in gene expression asymmetry (for a detailed discussion see Simões-Costa et al., 2005). Finally, it is possible to envision cardiac chambers not as discrete units but as the final outcome of patterning events taking place on a pumping structure; retinoic (RA) acid has been proposed to determine cardiac inflow and outflow segments in a model that includes localized presence of the RA-converting enzyme RALDH2, RA diffusion and perhaps a more efficient response to RA in the cells of the inflow region as compared to the outflow one (Simões-Costa et al., 2005; Xavier-Neto et al., 2007).

The primitive primary myocardium, as opposed to chamber myocardium, undergoes a deep remodelling through embryonic development, being incorporated into part of the chambers as in the case of the AV myocardium that integrates into the smooth walled regions of the atria (Lamers et al., 1992; Wessels et al., 1996). Whereas the chamber myocardium has a sustained proliferation that only stops after birth, the primitive myocardium proliferates at quite a low rate (Soufan et al., 2006). Most interestingly, localized regions of extremely low mitotic activity in the domain of primary myocardium correlate with the development of part of the conduction system (Sedmera et al., 2003; Thompson et al., 2003), a network of modified cardiomyocytes which constitutes the pacemaker of the heart and the fibres that rapidly convey the contraction impulses (Wessels et al., 1992; Oosthoek et al., 
1993a, b; Takebayashi-Suzuki et al., 2000; Moorman et al., 1998; Moorman and Christoffels, 2003; Mikawa and Hurtado, 2007). The primary myocardium, which is a slow substrate for the electric propagation mainly due to the absence of connexins like $\mathrm{C} \times 40$ or Cx43 also has a characteristic high automaticity and will specifically contribute to the formation of the sinus and atrioventricular nodes and the bundle of His. The distal portions of the conduction system, including Purkinje fibers, form from modified chamber myocardium (Moorman et al., 2005; Mikawa and Hurtado, 2007).

A complex transcriptional regulation network has recently been reported to control the differences between primary and chamber myocardium. In the centre of the network, the T-box transcription factor Tbx2 acts as a repressor of the differentiation of chamber myocardium. Such activity is exerted through the repression of Nppa (or atrial natriuretic factor, ANF) (Christoffels et al., 2004; Naiche et al., 2005; Hoogars et al., 2007a). Tbx2 expression domain is complementary to that of Nppa, $C \times 40, C \times 43$ and Chisel, genes that characterize chamber myocardium (Christoffels et al., 2004). Some additional members of the Tbx family like Tbx3 regulate the development of specific parts of the conduction system as it is the case of the sinus node (Mommersteeg et al., 2007; Hoogaars et al., 2007b), while T-box factors like Tbx20 and Tbx5 collaborate with Nkx2.5 and GATA4 in setting a chamber phenotype (Hoogaars et al., 2007a). The evolutionary importance of T-box transcription factors in myocardial development is illustrated by their conserved activity in regulating the proliferation of heart muscle in lower vertebrates like the zebrafish (Ribeiro et al., 2007).

T-box genes are also important in cardiac development in invertebrates, although their diversity is much lower. Extensive studies have been performed in the urochordate Ciona (Davidson and Levine, 2003; Takatori et al., 2004; Davidson, 2007), where nine T-box genes have been annotated (representatives of 7 of the $8 \mathrm{~T}$-box subfamilies, Davidson, 2007). Although there is not Ciona ortholog of $T b \times 4 / 5$ and $T b \times 20$ is not expressed in the embryo, $T b x 6$ (which is a duplicated locus in Ciona) seems to play a main role in cardiac development (Davidson, 2007). Tbx6band Tbx6c induce Mesp in cardiac progenitors in the stage of 110 cells. On the other hand, there is evidence that $T b \times 6$ (dorsocross) and $\mathrm{Tb} \times 20$ ( $h 15 /$ midline) orthologs are involved in the development of the Drosophilaheart (Reim and Frasch, 2005; Reim etal., 2005; Qian etal., 2005; Miskolczi-McCallum etal., 2005). It is thus tempting to suggest that the number of Tbx genes involved in cardiac development could be evolutionary linked to the progressive functional specialization of the myocardium and therefore to chamber development.

Another evident difference affecting heart muscle populations is that found between atrial and ventricular myocardial components, which display different contractile and electrophysiological activities. The regionalization of the working myocardium is a complex issue. In the chick, the regionalization starts as soon as in the straight heart tube as atrial myosin heavy chain proteins preferentially accumulate in caudal (posterior) positions of the tube (De Jong et al., 1987, 1990; Yutzey et al., 1994). The development of the mouse heart is slower than the chick one, and that can probably explain why regionalization of myocardial genes in the mouse is clear only after the heart looping starts (Lyons et al., 1990, 1994; Kelly et al., 1999). Defining boundaries in the transcriptional domains of specific contractile proteins is
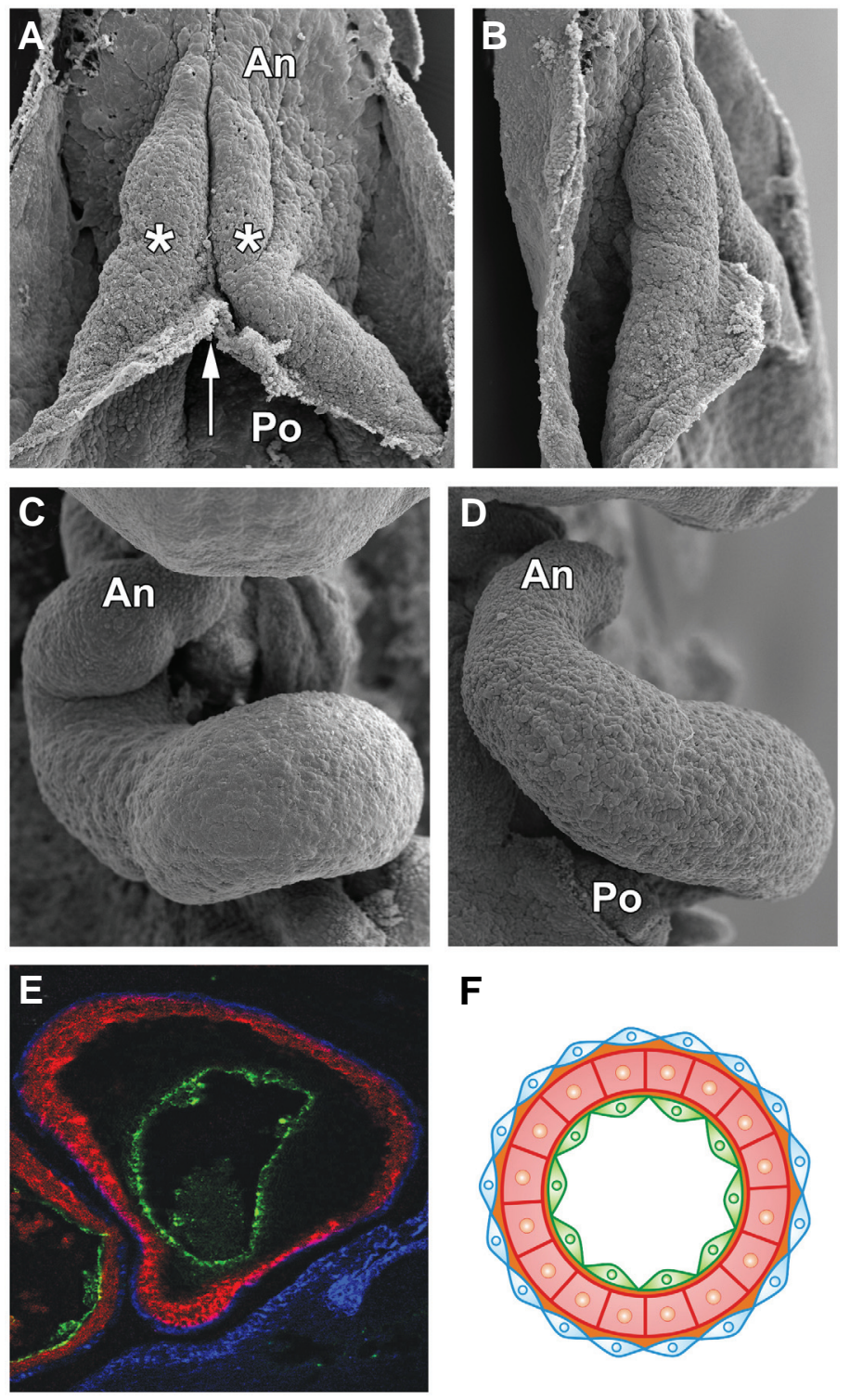

$\mathbf{F}$

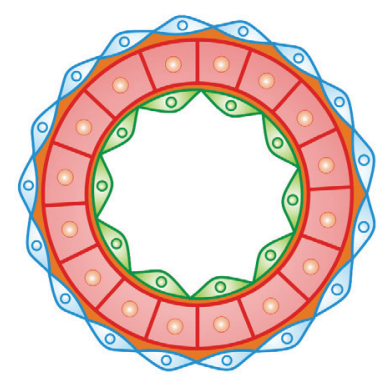

Fig. 4. Looping and layering of the heart. (A-D) The vertebrate heart looping is illustrated with scanning electron micrographs from chick embryos. (A) At HH9 the two bilateral cardiac tubes (asterisks) have just fused in the midline (arrow) forming a single straight heart tube. Anterior arterial (An) and posterior venous (Po) poles of the heart are indicated. (B) Shows a right lateral view of the same specimen with the same anteroposterior orientation. (C,D) Around 20 hours later HH14 embryos have initiated the C-shape phase of the cardiac looping. (C) A frontal view and (D) a right lateral one. (E,F) The characteristic layering of the heart. In (E), the endocardium (green), the myocardium (red) and the epicardium (blue) in a chick heart transversal section have been counterstained using an endothelium-specific lectin and antibodies against heavy myosins and cytokeratins, respectively. The concentric arrangement of the layers is shown in the cartoon in (F).

crucial to this process of regionalization. The issue is complex because different myosin chains restrict their expression domains early in development. This is the case of myosin light chain $2 \mathrm{v}$ (MLC2V) or $\beta$ myosin heavy chain ( $\beta \mathrm{MHC}$ ) which will basically become ventricular isoforms starting at E8.5 and E10.5 respec- 
tively (Lyons et al., 1990; O'Brien et al., 1993) whereas others remain expressed by different heart segments for a longer period of time. On the contrary other proteins like $\alpha$ myosin heavy chain $(\mathrm{MHC} \alpha)$ or myosin light chain $1 \mathrm{~A}(\mathrm{MLC} 1 \mathrm{~A})$ are expressed at different levels in both atria and ventricles (Lyons et al., 1990). MLC2v also accumulates in the ventricle of avians (Somi et al., 2006). Nevertheless, how chamber identity is defined is an aspect of cardiac development that still needs much attention. Different genes like $d H A N D 1$ and eHAND, as well as Iroquois 4 (Ir $\times 4)$ or Tb $\times 5$ have unique and restricted maps of expression but it is not fully clear how these genes are responsible (or interact with other informational or signalling systems) to influence at least three different pivotal aspects of cardiac chamber formation: 1) determination of L/R asymmetry, 2) control of myocardial proliferation, and 3) activation or blockade of specific contractile proteins synthesis.

\section{The origin of the endocardium}

The endocardium is the endothelial, innermost cell layer of the heart. The endocardial progenitor cells originate from the precardiac epithelium by an epithelial-mesenchymal transition (EMT) process. Whereas prospective endocardial cells downregulate $\mathrm{N}$-cadherin expression (Manasek, 1968; Linask and Lash, 1993) and migrate away towards the endoderm, muscle progenitors remain as an $\mathrm{N}$-cadherin-expressing population of cells covering the internal forming sheet of endocardium (Linask and Lash, 1993; Sugi and Markwald, 1996). Thus, endocardial and myocardial progenitors apparently originate from a same cellular population (Linask and Lash, 1993; Sugi and Markwald, 1996). It is not known whether there is a common endocardial/myocardial progenitor (Cohen-Gould and Mikawa, 1996), but a mesodermal cell line derived from quail embryos (QCE-6), is able to differentiate into myocardial and endothelial cells (Eisenberg and Bader, 1995).

Invertebrate hearts lack of endocardium, and this is another main difference with the vertebrate heart. The lack of endocardium is logically related to the lack of a true endothelium in the invertebrate vessels. Thus, the question about the evolutionary origin of the endocardium is directly connected to the hypothesis about the origin of the endothelium in vertebrates. We have published elsewhere a model about the origin of the vertebrate endothelium (Muñoz-Chápuli et al., 2005). We think that the endothelium derived in the vertebrate ancestors from a type of blood cell (frequently called the amoebocyte) which is able to adhere to the vascular basal laminae and migrate onto them. Amoebocytes are sometimes so abundant that they line most of the inner surface of the vessels, as it occurs in cephalopods (Budelmann etal., 1997). However, even in these cases, they lack of intercellular junctions and are still able to freely move, and therefore these cells cannot be considered a true endothelium.

The transition from specialized blood cells to an endothelium involved the acquisition of intercellular junction complexes. It is significant that endothelial cells use, for these complexes, molecules that are also found in blood cells or their progenitors, such as PECAM-1 (found in platelets and megacaryocytes) and cadherin-5 (expressed by hematopoietic progenitors) (Fraser et al., 2003). Thus, endothelium did not "invent" the system for becoming an epithelium, but simply used a set of molecules already present in their evolutionary progenitors.

How the hypothetical common progenitor of endocardium and myocardium can be reconciled with our model of blood cellderived endothelium? We think that this is possible if we consider some features of the invertebrate hemopoiesis. The evolutionary origin of blood cells resides probably in the coelomic epithelium (Hartenstein, 2006), i.e. the same cell sheet which is able to acquire contractile abilities and give rise to the cardiac wall. Primitive blood cells probably were delaminated coelomocytes with phagocytic abilities (Muñoz-Chápuli etal., 2005). Diversification of this primitive cell type allowed for acquisition of further functions in immunological defence and oxygen transport, but the coelomic evolutionary origin of the blood cells (and thus of the vertebrate endothelium) is probably recapitulated in the embryonic origin of the endocardium from the same coelomic sheet that gives rise to the myocardium. Thus, it is not surprising that the cell line QCE-6 above mentioned, which is able to differentiate in endocardium and myocardium, can also give rise to erythrocytes in culture (Eisenberg and Markwald, 1997). It might also be significant that a same transcriptional activator, Hand, be required for both, cardiogenesis and hemopoiesis in Drosophila(Han etal., 2006) under control of the GATA factors pannier and serpent, respectively.

We discussed before on the diversity of the myocardium and it is thus time to discuss if the endocardium can be regarded as a homogeneous population. Regionalization of the endocardium is not an evident phenomenon because the morphology and cellular phenotype of endocardial cells does not reveal intrinsic differences affecting this cell population. However, it is well known that only some endocardial cells (those lining the AV canal and the conal region) have the ability of undergoing EMT and thus form valvuloseptal mesenchymal cells (progenitors of cardiac valve leaflets). Experimental studies in chick and mouse embryos using the collagen gel explant assay strongly support this point (Bernanke and Markwald, 1982; Runyan and Markwald, 1983; Mjaatvedt and Markwald, 1989; Timmerman et al., 2004).

A diversity of members of the TGF $\beta$ superfamily, their receptors and transducers (including TGF $\beta$ s, BMPs, TGFRs and Smads) have been reported to be responsible for the triggering of endocardial EMT (Potts and Runyan, 1989; Brown et al., 1996. 1999; Ramsdell and Markwald, 1997; Nakajima et al., 1998; Galvin et al., 2000; Romano and Runyan, 2000; Gaussin et al., 2002, 2005; Jiao et al., 2003). Other signalling molecules like VEGF or signalling pathways like the NFATc1/calcineurin one are also known to be of extreme importance in modulating embryonic valve development (de la Pompa et al., 1998; Dor et al., 2001; Chang et al., 2004).

A special case is that of the Notch signalling pathway. Notch is an ancient local cell-to-cell signaling system that has been nicely preserved through evolution. Both the receptors (Notch1-4) and ligands (Delta and Jagged family members) in the pathway are membrane bound. Notch, which is involved in regulating cell fate decisions in vertebrates and invertebrates (Artavanis-Tsakonas et al., 1999), has been recently reported to be regulated by microRNAs (miRNAs) during cardiac differentiation in Drosophila (Kwon et al., 2005). miRNAs are small non coding RNAs known to be expressed in a tissue-specific manner in vertebrates and invertebrates and have been shown to represent an alternative regulatory mode of development mainly based in cell-specific 
inhibition of translation (Kwon etal., 2005; Zhao et al., 2005, 2007; Zhao and Srivastava, 2007).

In vertebrate development Notch activity is clearly different between distinct endocardial domains, since the pathway is involved in the promotion of $\mathrm{AV}$ valve EMT acting through the cadherin repressor Snail (Timmerman et al., 2004) as well as in the coordination of the endocardial signals (translocated from the endocardium to the myocardium via the endocardially-secreted neuregulin 1 and its myocardial Erb receptors) that activate the trabeculated phenotype characteristic of the ventricular chambers (Grego-Bessa et al., 2007). Local activation of Notch is known to initiate a lateral inhibition mechanism acting as a pattern generator in many tissues (Bray, 1998; Artavanis-Tsakonas, 1999; Kurata et al., 2000; Morrison et al., 2000). However, Notch may also act eliciting lateral activation mechanisms that would spread Notch activity in certain areas, what might in turn lead to the appearance of territories of cellular competence (Timmerman et al., 2004; Grego-Bessa et al., 2007). In the case of the endocardium, Notch could thus be responsible for outlining developmental borders in the apparently homogeneous endocardium.

\section{The origin of the epicardium and the cardiac vessels}

The epicardium is the outer layer of the vertebrate heart. A coelomic epithelium is sometimes found on the surface of the invertebrate hearts, but the ontogenetic origin of the vertebrate epicardium makes it unique among the outer cardiac cellular linings. The vertebrate epicardium originates from an outgrowth of coelomic cells, called the proepicardium, which develops in the posterior limit of the heart, between the sinus venosus and the liver, around the area of the transverse septum (Manner et al., 2001). Proepicardial cells attach to and spread over the myocardial surface giving rise to the epicardium. Mesenchymal cells present in the proepicardium and delaminated from the epicardium invade the subepicardial space and the myocardium and contribute to the cardiac vessels and the connective tissue of the heart (Fig. 5).

The proepicardium is paired in fish, only a right proepicardium develops in birds and in mammals the two original primordia fuse in the midline covering the whole septum transversum area. No hypothesis was available in the literature about the origin of the paired coelomic outgrowths which constitute the proepicardium. We have recently studied the development of the epicardium in lampreys, representatives of the most primitive vertebrate lineage, the agnathans. We have shown that the proepicardium, in lamprey prolarvae, derives from the primordia of a pair of primitive pronephric external glomeruli, which are still functional in larval stages (Pombal et al., 2008). The lamprey proepicardium is, in this way, an element of the pronephros. In fact the venous pole of the heart, in these primitive vertebrates, is anatomically related with the pronephros, and not with the liver as it happens in other vertebrates. This finding explains not only the evolutionary origin of the proepicardium/epicardium, but also two intriguing features of these tissues. First, the epicardial expression of genes related with the excretory system. This is the case of the transcription factors Wt1 (Wilms' tumor suppresor gene), Pod-1/epicardin (Moore et al., 1998; Quaggin et al., 1999) and Tbx18 (Airik et al., 2006; Christoffels et al., 2006). Second, the high vasculogenic potential of the proepicardial cells (Pérez-Pomares et al., 2006) can be related with its original function of developing a vascular network for blood filtering in the external glomerulus.

We think that the involvement of a derivative from the external pronephric glomerulus in cardiac development accounts for a number of major differences between the vertebrate and invertebrate hearts, such as the development of cardiac vessels. On the other hand we can speculate about an evolutionary relationship existing between the heart-glomerulus connection in vertebrates and the peculiar heart-kidney complex of hemichordates, the deuterostome phylum phylogenetically closest to the chordates. This complex, which we have mentioned above, is constituted of a large glomerulus connected to a pulsatile vessel (Benito and Pardos, 1997). The relationship between these organs could be discarded at a first glance due to their different topological location. The heart is ventral and postpharyngeal in vertebrates, while the heart-kidney complex of hemichordates is preoral and dorsal respect to the gut. However, as already indicated, this difference could not be relevant because the dorsal-ventral axis of hemichordates is probably reversed respect to that of vertebrates. In fact, the expression of "dorsal" genes such as Chordin is ventral in hemichordates, while "ventral" and cardiac-related genes such as BMP2, NkX2.5or Tbx2-3are expressed dorsally in hemichordates (Lowe et al., 2006). Thus, the primordium of the pronephric external glomerulus which contacts to the heart in lamprey prolarvae and the heart-kidney complex of hemichordates show a similar topological localization. The hypothetical homology of these structures suggests that the proepicardium may represent the last vestige of a kidney-heart complex which was present in the ancestors of chordates, although it was lost in urochordates and cephalochordates.

The transfer of vasculogenic glomerular cell progenitors to the primitive vertebrate heart was coupled with the development of a multilayered and trabeculated heart wall that soon needed a vascular supply other than the venous blood flow circulating through the cardiac lumen. It is conceivable that the original coronary system was constituted only by capillaries and veins. A venous network over the cardiac surface, even in the absence of coronary arteries, probably allowed for draining of blood from the intertrabecular sinusoids, thus improving the circulation of blood through the outer myocardial layer (Tota et al., 1983). The further increase of the cardiac wall thickness and the subsequent cardiac performance in large fish made this system not enough for the metabolic needs of the myocardium. These needs were probably satisfied by coronary arteries developing from the hypobranchial arteries which receive oxygenated blood supply directly from the efferent branchial arteries. This temporal uncoupling in the development of coronary arteries and cardiac veins has been described in embryos of the elasmobranch Scyliorhinus canicula (De Andrés et al., 1993).

\section{The contribution of the neural crest}

A final difference between the vertebrate and invertebrate hearts is accounted by the contribution of cells from the neural crest, a cell population which is exclusive of vertebrates although the genetic program leading to its development is partially present in non-vertebrate chordates (Barrallo-Gimeno and Nieto, 2006). The neural crest is constituted of a cell population which originates from the margins of the neural plate and migrates through- 
A

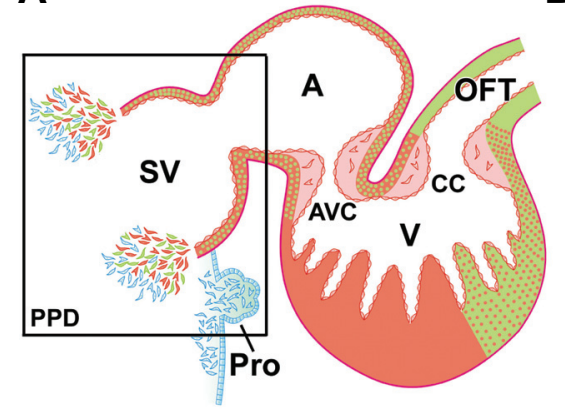

B

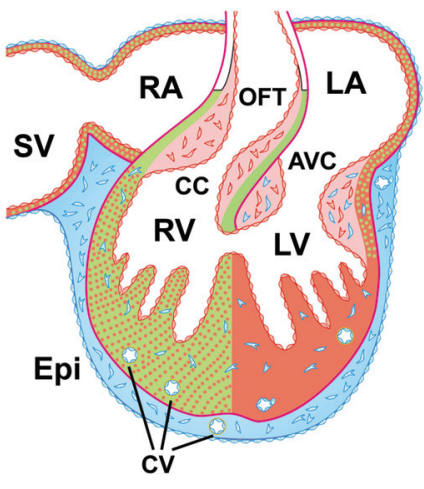

Fig. 5. Proepicardial contributions to heart development. (A,B) Translocation of the epicardial progenitors from the "extracardiac" proepicardium (Pro) to the primitive epicardium (Epi). The red-green code color has been kept to indicate PHF or SHF contributions. In (B) epicardially-derived cells (EPDCs) have already invaded the atrioventricular and ventricular subepicardial space and compact myocardial layers to form coronary vessels (CV). Invasive mesenchymal populations not associated to the coronaries remain in this myocardium and reach the atrioventricular cushions (AVC). The boxed area in (A) has been magnified in (C) to show a hypothesis about the interaction of two pools of cardiac progenitors (from the PHF in red and the SHF in green) with a

C

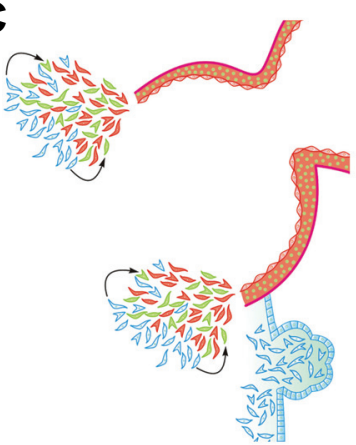

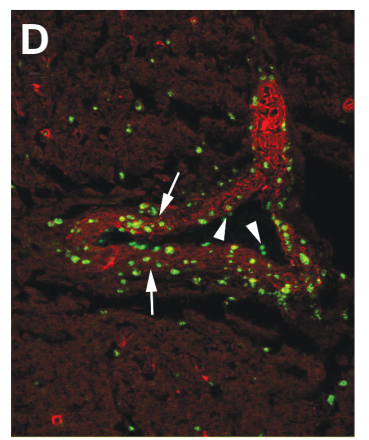

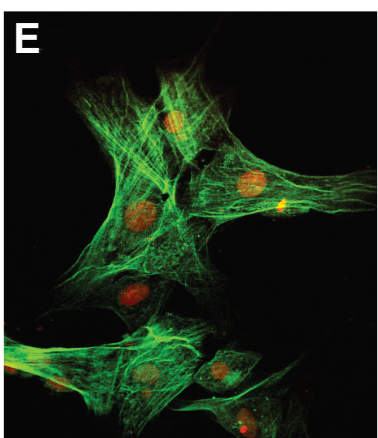
population of coelomic-derived cells (in blue) at the heart inflow. This latter population of cells would represent at least part of the posterior pronephric domain $P P D$, see text for a detailed explanation) that coincides in time and space with cardiac precursors contributing to the morphogenesis of the area, probably by signalling (arrows) to the myocardial progenitors. (D) Aspects of coronary vessel formation from proepicardial cells in a quail to chick proepicardial chimera (see PérezPomares et al., 2002 for details on the transplantation procedure). Note that quail proepicardial cells (green dots) form both the endothelial layer (arrowheads) and smooth muscle wall (arrows, counterstained in red with antibodies against smooth muscle alpha-actin, $\alpha$-SMA). Some migratory EPDCs ( $\alpha$-SMA-positive) express the coelomic lineage marker Wilms tumor transcription factor (Wt1) in their nuclei (red) for a certain period of time. Abbreviations: AVC, atrioventricular cushions; $C C$, conal cushions; $L A$, left atrium; $L V$, left ventricle; RA; right atrium; $R V$, right ventricle.

out the embryo giving rise to multiple derivatives. The so-called "cardiac" neural crest originates between the otic vesicle and the third somite. Besides the contribution of neural crest cells to the parasympathetic ganglia of the heart, they are required to form the aortico-pulmonary septum dividing the cardiac arterial pole into the ascending aorta and the pulmonary trunk and also they provide signals required for the maintenance and differentiation of the other cell layers in the pharyngeal arches (Brown and Baldwin, 2006; Hutson and Kirby, 2007). In zebrafish, even myocardial differentiation of cardiac neural crest cells has been described ( $\mathrm{Li}$ et al., 2003; Sato and Yost, 2003). Recently, cardiac neural crest cells have been shown to modulate signalling in the pharynx during the lengthening of the outflow tract, and in fact the neural crest is required for the addition of new myocardium to the outflow tract from the secondary heart field (Waldo et al., 2005; Hutson et al., 2006). Thus, anomalies in the interactions between cardiac neural crest cells, endoderm and the cells of the anterior secondary heart field results in defective outflow tract development (Chen et al., 2007; Goddeeris et al., 2007).

\section{The role of tissue interactions and heart looping in cardiac morphogenesis}

At this point we should ask ourselves whether the regulation of myocardial differentiation is intrinsic to this tissue and thus independent and isolated from any other sort of external information. Recent results seem to indicate that this is not the case as targeted deletion of genes relevant to the development of nonmuscular tissues like the endocardium and the epicardium has a great impact on the proliferation, differentiation and maturation of the myocardium and thus the specific myocardial morphologies found in different heart regions. The importance of the signals provided by the endocardium on the inner surface of the heart and the epicardium on the outer has clear examples in trabeculation and compact myocardial layer proliferation.

The trabeculae are a characteristic feature of the early ventricle (actually, the most characteristic feature of any vertebrate heart ventricle) and confer to this embryonic cardiac chamber its typical spongy appearance. Trabeculae are highly organized sheets of cardiomyocytes that form muscular ridges or projections lined by endocardial cells (Ben-Shachar et al., 1985). Trabeculae will progressively become part of papillary muscles, the interventricular septum, and part of the conduction system (Moorman and Christoffels, 2003).

Different molecules have been reported to be involved in trabeculation (Gassman et al., 1995; Lee et al., 1995; Meyer and Birchmeier, 1995; Wang et al., 1998; Gerety et al., 1999; Chen et al., 2004), but a recent report indicates that the Notch pathway is responsible for the coordination of the events leading to trabeculae formation. Notch1 is expressed by endocardial and not by myocardial cells. Notch1 is active specifically at the presumptive trabecular regions. Embryos lacking Notch signalling elements show defective trabeculation and reduced ventricle-specific endocardial and myocardial gene expression. Furthermore, endocardial specific Notch1 deletion shows similar defects (GregoBessa et al., 2007). This suggests that the communication between the endocardium and the myocardium is impaired and that the signals that emanate from the former are required by the latter to develop. Notch signal has an impact on myocardial proliferation through myocardial BMP10 expression, which is disrupted in 
A

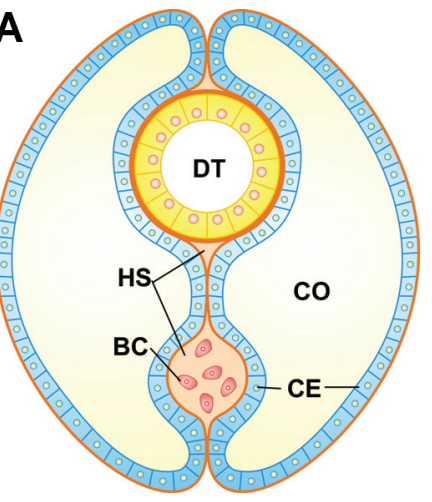

B

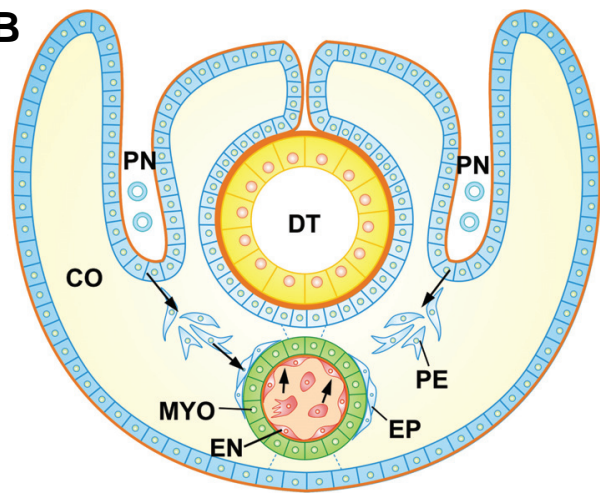

Fig. 6. Extracardiac cell contributions give rise to the trilayered vertebrate heart. Blood-pumping organs are shown in the context of the coelomic cavity. (A) Invertebrate hearts are frequently constituted only by a single layer of myoepithelial cells. (B) The vertebrate heart is characterized by a multilayered myocardium (MYO) lined internally and externally by an endocardium (EN) and an epicardium (EP). From the evolutionary point of view, we suggest that the endocardium, as well as all the vertebrate endothelium, derives from a specialized type of blood cell (Muñoz-Chápuli et al., 2005). On the other hand, the epicardium develops from the attachment to the surface of the heart of proepicardial cells (PE) which arose from an ancestral pronephric external glomerulus (Pombal et al., 2008). Endocardium and epicardium have the potential to give rise to mesenchymal cells which will contribute to the valvuloseptal mesenchyme, the coronary vessels and the connective tissue of the heart. A third extracardiac contribution, that from the neural crest, has not been included in the scheme. BC: blood cells; $P N$ : pronephros. Other abbreviations as in precedent figures.

Notch mutants. A second intermediate system related to Notch effects is that represented by the cell-to-cell signalling system EphrinB2/EphB4. EphrinB2 expression is actively promoted by Notch in the endocardium, which in turn indirectly contributes to the expression of the soluble Neuregulin 1 (NRG1). Myocardial NRG1 receptors of the ErbB type finally receive the signal promoting myocardial differentiation (Grego-Bessa et al., 2007).

Although the presence of a compact ventricular layer is not characteristic of all vertebrate hearts, its presence can already be recorded in primitive vertebrates like sharks. The compact layer of the myocardium originates from the primitive epithelial walls of the cardiac ventricles. The myocardial thickening of heart walls coincides in time with the development of the epicardium. Disruption of the expression of epicardial-specific molecules in the heart like Wt1 does not only alter epicardial development, but also reduces compact myocardium proliferation, yielding a characteristic "thin myocardial" phenotype (Moore et al., 1999). Wt1-null mice show a deficiency in RALDH2 synthesis. RALDH2 is the main retinoic acid (RA)-synthesizing enzyme in the embryo. RA seems to have an autocrine signalling function, acting on the EPDC and inducing the production of an unknown trophic factor which stimulates the myocardial proliferation (Perez-Pomares et al., 2002b; Chen etal., 2002, Stuckmann etal., 2003; Lavine et al., 2006). These results, taken together, are a strong support for the concept of the epicardium as other non-muscular embryonic tissue critical to myocardial development.

At the same time the heart becomes more diverse in terms of its cellular components it also initiates and completes a torsion movement. It is easy to understand that the serial arrangement of cardiac domains in the straight heart tube enormously limits the progression towards a more complex heart. This limitation be- comes obvious with the invasion of land territories by primitive vertebrates. From the starting point of the fish heart bauplan (a single tube looped to the right side), the heart tube will rearrange in space until being transformed into an organ with four predominant chambers (two atria and two ventricles) that work in parallel and are able to distribute the blood through systemic and pulmonary circuitries. Dextral looping is a characteristic feature of the vertebrate heart. Even in the rare cases in which the invertebrate body develops asymmetrically (e.g. In Amphioxus), the mid ventral vessel which putatively correspond to the heart remain as a linear straight tube. An exception to this rule can be found in the urochordate Ciona, where the heart tube is folded towards the dorsal side and shows a typical V shape (Davidson et al., 2007), but the relationship of this observation with the vertebrate cardiac looping is uncertain.

In a certain way, the cardiac looping, considered as a sequential change in position of distinct cardiac regions, cannot be separated from the morphological changes that affect different cardiac domains (i.e. formation of chamber myocardium, remodelling of primary myocardium and so on). Nevertheless, several characteristic movements of the heart can be recognized as important features of the looping process, mainly the "rightward" aspect of it. In a normal situation the heart starts to bend and protrudes to the right side of the embryo in what is known as Rloop; this movement involves a rotation of the tube in the craniocaudal axis, so that the original ventral side of the tube is lateralized forming, at this stage, the outer curvature of the heart. If this R-loop transforms the straight heart tube into a C-shaped structure (De Haan, 1965; Stalsberg, 1970), then the lateral displacement of the arterial and venous poles of the heart tube and the "shortening" of the distance between these two areas (following the cranio-caudal axis) determine the conversion into a S-shaped conformation in which embryonic atria become cranial to the ventricles (De la Cruz, 1998; Taber, 1998). Most authors agree in considering the end of the S-shaped heart phase as the end of cardiac looping (De la Cruz, 1998; Taber, 1998), whereas others would like to consider that the looping is not really terminated until cardiac chambers are completely aligned and septated (Steding and Seidl, 1980; Männer et al., 1993; Männer, 2000; Cardiac looping and layering events are summarized in Figure 4).

\section{Conclusion}

The vertebrate heart is unique among the metazoan blood pumping organs but, at the same time, it is possible to account for the origin of most of its exclusive features from the analysis of developmental and comparative data. The establishment of a specific program of myocardial differentiation superimposed to the visceral myogenic original program, the recruitment of mesodermal cells from both ends of the primary cardiac tube, as well as the incorporation of extrinsic cell populations with diverse origins contributed to develop an organ which was pivotal for the evolutionary expansion of vertebrates. The success of the vertebrate 
heart depended on the morphogenetic and signalling properties of mesenchymal tissues derived from the endocardium (that most likely, like the rest of the vertebrate endothelium, originated from blood cells), the epicardium or the neural crest (summarized in Figure 6). All these tissues were crucial to the development of the sophisticated vertebrate heart that allowed this group of organisms to become exceptionally large and active animals.

\section{References}

ABU-ISSA, R., and KIRBY, M.L. (2007). Heart field: from mesoderm to heart tube. Annu. Rev. Cell Dev. Biol. 23: 45-68.

ABU-ISSA, R., WALDO, K. and KIRBY, M.L. (2004). Heart fields: one, two or more? Dev. Biol. 272: 281-285.

AIRIK, R., BUSSEN, M., SINGH, M.K., PETRY, M., and KISPERT, A. (2006) Tbx18 regulates the development of the ureteral mesenchyme. J. Clin. Invest. 116:663674.

ARGÜELLO, C., DE LA CRUZ, M.V. and GOMEZ, C.S. (1975). Experimental study of the formation of the heart tube in the chick embryo. J. Embryol. Exp. Morphol. 33:1-11.

ARTAVANIS-TSAKONAS, S., RAND, M.D., and LAKE, R.J. (1999) Notch signaling: cell fate control and signal integration in development. Science 284:770776.

BALDINI, A. (2005). Dissecting contiguous gene defects: TBX1. Curr. Opin. Genet. Dev. 15: 279-284.

BARRALLO-GIMENO, A., NIETO, M.A. (2006) Evolution of the neural crest. Adv. Exp. Med. Biol. 589:235-244.

BENITO, J., AND PARDOS, F. (1997) Hemichordata. In: Microscopic Anatomy of Invertebrates (Eds. Harrison, F. W. and Ruppert, E. E.) Vol. 15, Hemichordata, Chaethognatha and the invertebrate Chordates. Wiley-Liss, New York., pp.15102.

BEN-SHACHAR, G., ARCILLA, R.A., LUCAS, R.V. and MANASEK, F.J. (1985). Ventricular trabeculations in the chick embryo heart and their contribution to ventricular and muscular septal development. Circ. Res. 57: 759-766.

BERNANKE, D.H., and MARKWALD, R.R. (1982) Migratory behavior of cardiac cushion tissue cells in a collagen-lattice culture system. Dev. Biol. 91:235-245.

BLACK, B.L. and OLSON, E.N. (1998). Transcriptional control of muscle development by myocyte enhancer factor-2 (MEF2) proteins. Annu. Rev. Cell. Dev. Biol.14: 167-196.

BODMER, R. (1993). The gene tinman is required for specification of the heart and visceral muscles in Drosophila. Development 118: 719-729.

BODMER, R. and FRASCH, M. (1999) Genetic determination of Drosophila heart development. In: Heart Development (Eds. Harvey, R.P. and Rosenthal, N.) Academic Press, San Diego, pp. 65-90.

BODMER, R., JAN, L.Y. and JAN, Y.N. (1990). A new homeobox-containing gene, $m s h-2$, is transiently expressed early during mesoderm formation in Drosophila. Development 110: 661-669.

BOVERI, T. (1910). Die Potenzen der Ascaris-Blastomeren bei abgeänderter Furchung, zugleich ein Beitrag zur Frage qualitativ-ungleicher ChromosomenTeilung. Festschrift für Richard Hertwig, vol. 3. Gustav Fischer, Jena.

BRAY, S.J. (2006) Notch signalling: a simple pathway becomes complex. Nat. Rev. Mol. Cell. Biol. 7:678-689.

BROWN, C.B., and BALDWIN, H.S. (2006) Neural crest contribution to the cardiovascular system. Adv. Exp. Med. Biol. 589:134-154.

BROWN, C.B., BOYER, A.S., RUNYAN, R.B., and BARNETT, J.V. (1996) Antibodies to the type II TGFbeta receptor block cell activation and migration during atrioventricular cushion transformation in the heart. Dev. Biol. 174:248-257.

BROWN, C.B., BOYER, A.S., RUNYAN, R.B., and BARNETT, J.V. (1999) Requirement of type III TGF-beta receptor for endocardial cell transformation in the heart. Science 283:2080-2082

BUCKINGHAM, M., MEILHAC, S. and ZAFFRAN, S. (2005). Building the mammalian heart from two sources of myocardial cells. Nat. Rev. Genet. 6: 826-837.

BUDELMANN, B.U., SCHIPP, R., AND VON BOLETZKY, S. (1997) Cephalopoda.
In: Microscopic Anatomy of Invertebrates (Eds. Harrison, F. W. and Kohn, A. J.). Vol. 6A, Molluscs. Wiley-Liss, New York., pp. 119-414.

BURIGHEL, P., and CLONEY, R.A. (1997) Urochordata: Ascidiacea. In: Micro scopic Anatomy of Invertebrates (Eds. Harrison, F. W. and Ruppert, E. E.). Vol. 15 , Hemichordata, Chaethognatha and the invertebrate Chordates. Wiley-Liss, New York., pp. 221-348.

CAI, C.L., LIANG, X., SHI, Y., CHU, P.H., PFAFF, S.L., CHEN, J. and EVANS, S. (2003). /s/1 identifies a cardiac progenitor population that proliferates prior to differentiation and contributes a majority of cells to the heart. Dev. Cel/5: 877889

CAMPIONE, M., STEINBEISSER, H., SCHWEICKERT, A., DEISSLER, K., VAN BEBBER, LOWE, L.A., NOWOTSCHIN, S., VIEBAHN, C., HAFFTER, P., KUEHN, M.R. and BLUM, M. (1999). The homeobox gene Pitx2: mediator of asymmetric left-right signaling in vertebrate heart and gut looping. Development 126: $1225-1234$

CHANG, C.P., NEILSON, J.R., BAYLE, J.H., GESTWICKI, J.E., KUO, A., STANKUNAS, K., GRAEF, I.A., and CRABTREE, G.R. (2004) A field of myocardial-endocardial NFAT signaling underlies heart valve morphogenesis. Cell118:649-663.

CHEN, H., SHI, S., ACOSTA, L., LI, W., LU, J., BAO, S., CHEN, Z., YANG, Z., SCHNEIDER, M.D., CHIEN, K.R., CONWAY, S.J., YODER, M.C., HANELINE, L.S., FRANCO, D. and SHOU, W. (2004). BMP10 is essential for maintaining cardiac growth during murine cardiogenesis. Development 131: 2219-2231.

CHEN, T.H., CHANG, T.C., KANG, J.O., CHOUDHARY, B., MAKITA, T., TRAN, C.M., BURCH, J.B., EID, H. and SUCOV, H.M. (2002). Epicardial induction of fetal cardiomyocyte proliferation via a retinoic acid-inducible trophic factor. Dev. Biol. 250: 198-207.

CHEN, Y.H., ISHII, M., SUN, J., SUCOV, H.M., and MAXSON, R.E. Jr. (2007) Msx1 and Msx2 regulate survival of secondary heart field precursors and postmigratory proliferation of cardiac neural crest in the outflow tract. Dev. Biol. Epub ahead of print.

CHIA, F.S., and KOSS, R. (1982) Fine structure of the larval rhinophores of the nudibranch, Rostanga pulchra, with emphasis on the sensory receptor cells. Cell Tissue Res. 225:235-248.

CHRISTOFFELS, V.M., HOOGAARS, W.M., TESSARI, A., CLOUT, D.E., MOORMAN, A.F. and CAMPIONE, M. (2004). T-box transcription factor Tbx2 represses differentiation and formation of the cardiac chambers. Dev. Dyn.229: 763-770.

CHRISTOFFELS, V.M., MOMMERSTEEG, M.T., TROWE, M.O., PRALL, O.W., DE GIER-DE VRIES, C., SOUFAN, A.T., BUSSEN, M., SCHUSTER-GOSSLER, K., HARVEY, R.P., MOORMAN, A.F., and KISPERT, A. (2006) Formation of the venous pole of the heart from an Nkx2-5-negative precursor population requires Tbx18. Circ. Res. 98:1555-1563.

COHEN-COULD, L. and MIKAWA, T. (1996).ÄThe fate diversity of mesodermal cells within the heart field during chicken early embryogenesis. Dev. Biol.177: 265-273.

COLAS, J.-F., LAWSON, A. and SCHOENWOLF, G.C. (2000). Evidence that translation of smooth muscle alpha-actin mRNA is delayed in the chick promyocardium until fusion of the bilateral heart-forming regions. Dev. Dyn. 218: 316-330.

COLLOP, A.H., BROOMFIELD, J.A., CHANDRARATNA, R.A., YONG, Z., DEIMLING, S.J., KOLKER, S.J., WEEKS, D.L., and DRYSDALE, T.A. (2006) Retinoic acid signaling is essential for formation of the heart tube in Xenopus. Dev. Biol. 291: 96-109.

CROISSANT, J.D., KIM, J.H., EICHELE, G., GOERING, L., LOUGH, J., PRYWES R., and SCHWARTZ, R.J. (1996). Avian serum response factor expression restricted primarily to muscle cell lineages is required for alpha-actin gene transcription. Dev. Biol.177: 250-264.

DAVIDSON, B. (2007) Ciona intestinalis as a model for cardiac development. Semin. Cell. Dev. Biol. 18:16-26.

DAVIDSON, B., and LEVINE, M. (2003) Evolutionary origins of the vertebrate heart: Specification of the cardiac lineage in Ciona intestinalis. Proc. Natl. Acad. Sci. USA 100:11469-11473.

DAVIDSON, B., SHI, W., BEH, J., CHRISTIAEN, L. and LEVINE, M. (2006). FGF signaling delineates the cardiac progenitor field in the simple chordate, Ciona intestinalis. Genes Dev. 20: 2728-2738. 
DAVIS, C.L. (1927). Development of the human heart from its first appearance to the stage found in embryos of twenty paired somites. Carnegie Inst Wash Pub/ 380 Contrib Embryol 19: 245-283.

DE ANDRÉS, A.V., MUÑOZ-CHÁPULI, R., and SANS-COMA, V. (1993) Development of the coronary arteries and cardiac veins in the dogfish (Scyliorhinus canicula). Anat. Rec. 235:436-442.

DE JONG, F., GEERTS, W.J. LAMERS, W.H., LOS, J.A. and MOORMAN, A.F. (1987) Isomyosin expression patterns in tubular stages of chicken heart development: a 3-D immunohistochemical analysis. Anat. Embryol. 177: 81-90.

DE JONG, F., GEERTS, W.J., LAMERS, W.H., LOS, J.A. and MOORMAN, A.F. (1990). Isomyosin expression pattern during formation of the tubular chicken heart: a three-dimensional immunohistochemical analysis. Anat. Rec. 226:213227.

DE LA CRUZ, M.V. (1998). Torsion and looping of the cardiac tube and primitive cardiac segments. Anatomical manifestations. In Living morphogenesis of the heart (ed. de la Cruz, M.V. and Markwald, R.R.). Birkhauser, Boston, MA., pp. 99-119.

DE LA POMPA, J. L., TIMMERMAN, L. A., TAKIMOTO, H., YOSHIDA, H., ELIA, A. J., SAMPER, E., POTTER, J., WAKEHAM, A., MARENGERE, L., LANGILLE, B. L., CRABTREE, G. R., and MAK, T. W. (1998). Role of the NF-ATc transcription factor in morphogenesis of cardiac valves and septum. Nature 392:182-186

DEHAAN, R.L. (1965). Morphogenesis of the vertebrate heart. In Organogenesis (Eds. DeHaan, R.L. andUrsprung, H.). Holt Rinehart \& Winston. New York, N.Y., pp. 377-419.

EISENBERG, C.A., and BADER, D. (1995) QCE-6: a clonal cell line with cardiac myogenic and endothelial cell potentials. Dev. Biol. 167:469-481.

EISENBERG, C.A., and MARKWALD, R.R. (1997) Mixed cultures of avian blastoderm cells and the quail mesoderm cell line QCE- 6 provide evidence for the pluripotentiality of early mesoderm. Dev. Biol. 191:167-181.

EISENBERG, L.M. (2002). Belief vs. scientific observation: the curious story of the precardiac mesoderm. Anat. Rec. 266: 194-197.

EVANS, S.M. (1999). Vertebrate tinman homologues and cardiac differentiation. Semin. Cell. Dev. Biol.10: 73-83.

FERNÁNDEZ, J., TÉLLEZ, V., and OLEA, N. (1992) Hirudinea. In: Microscopic Anatomy of Invertebrates (Eds. Harrison, F.W. and Gardiner, S.L.). Vol. 7, Annelida. Wiley-Liss, New York., pp. 323-394.

FRASER, S.T., OGAWA, M., YOKOMIZO, T., ITO, Y., NISHIKAWA, S., and NISHIKAWA, S. (2003) Putative intermediate precursor between hematogenic endothelial cells and blood cells in the developing embryo. Dev. Growth Differ. 45:63-75.

GAJEWSKI, K., ZHANG, Q., CHOI, C.Y., FOSSETT, N., DANG, A., KIM, Y.H., KIM Y. and SCHULZ, R.A. Pannieris a transcriptional target and partner of Tinman during Drosophila cardiogenesis. Dev. Biol. 233: 425-436.

GALVIN, K.M., DONOVAN, M.J., LYNCH, C.A., MEYER, R.I., PAUL, R.J., LORENZ, J.N., FAIRCHILD-HUNTRESS, V., DIXON, K.L., DUNMORE, J.H., GIMBRONE, M.A. Jr, FALB, D., and HUSZAR, D. (2000) A role for smad6 in development and homeostasis of the cardiovascular system. Nat. Genet. 24:171-174.

GARCÍA-MARTÍNEZ, V., DARNELL, D.K., SOSIC, D., OLSON, E.N., and SCHOENWOLF, G.C. (1997). State of commitment of prospective neural plate and prospective mesoderm in late gastrula/early neurula stages of avian embryos. Dev. Biol.181: 102-115.

GASSMANN, M., CASAGRANDA, F., ORIOLI, D., SIMON, H., LAI, C., KLEIN, R., and LEMKE, G. (1995). Aberrant neural and cardiac development in mice lacking the ErbB4 neuregulin receptor. Nature 378: 390-394.

GAUSSIN, V., MORLEY, G.E., COX, L., ZWIJSEN, A., VANCE, K.M., EMILE, L., TIAN, Y., LIU, J., HONG, C., MYERS, D., CONWAY, S.J., DEPRE, C., MISHINA, Y., BEHRINGER, R.R., HANKS, M.C., SCHNEIDER, M.D., HUYLEBROECK, D., FISHMAN, G.I., BURCH, J.B., and VATNER, S.F. (2005) Alk3/Bmpr1a receptor is required for development of the atrioventricular canal into valves and annulus fibrosus. Circ. Res. 97:219-226

GAUSSIN, V., VAN DE PUTTE, T., MISHINA, Y., HANKS, M.C., ZWIJSEN, A., HUYLEBROECK, D., BEHRINGER, R.R., and SCHNEIDER, M.D. (2002) Endocardial cushion and myocardial defects after cardiac myocyte-specific conditional deletion of the bone morphogenetic protein receptor ALK3. Proc. Natl. Acad. Sci. USA 99:2878-2883.
GERETY, S.S., WANG, H.U., CHEN, Z.F., and ANDERSON, D.J. (1999). Symmetrical mutant phenotypes of the receptor EphB4 and its specific transmembrane ligand ephrin-B2 in cardiovascular development. Mol. Cel/4: 403-414.

GERHART J. (2006) The deuterostome ancestor. J. Cell Physiol. 209:677-685.

GITTENBERGER-DE GROOT, A.C., MAHTAB, E.A., HAHURIJ, N.D., WISSE, L.J., DE RUITER, M.C, WIJFFELS, M.C. and POELMANN, R.E. (2007). Nkx2.5negative myocardium of the posterior heart field and its correlation with podoplanin expression in cells from the developing cardiac pacemaking and conduction system. Anat. Rec. 290: 115-122.

GODDEERIS, M.M., SCHWARTZ, R., KLINGENSMITH, J., and MEYERS, E.N (2007) Independent requirements for Hedgehog signaling by both the anterior heart field and neural crest cells for outflow tract development. Development 134:1593-1604

GREGO-BESSA, J., LUNA-ZURITA, L., DEL MONTE, G., BOLOS, V., MELGAR, P., ARANDILLA, A., GARRATT, A.N., ZANG, H., MUKOUYAMA, Y.S., CHEN, H., SHOU, W., BALLESTAR, E., ESTELLER, M., ROJAS, A., PEREZ-POMARES, J.M., and DE LA POMPA, J.L. (2007) Notch signaling is essential for ventricular chamber development. Dev. Cel/12:415-429.

HAN, Z. and OLSON, E.N. (2005). Hand is a direct target of Tinman and GATA factors during Drosophila cardiogenesis and hematopoiesis. Development 132: 3525-3536.

HAN, Z., YI, P., LI, X., and OLSON, E.N. (2006) Hand, an evolutionarily conserved bHLH transcription factor required for Drosophila cardiogenesis and hematopoiesis. Development 133:1175-1182.

HARTENSTEIN, V. (2006) Blood cells and blood cell development in the animal kingdom. Annu. Rev. Cell Dev. Biol. 22:677-712.

HAUN, C., ALEXANDER, J., STAINIER, D.Y. AND OKKEMA, P.G. (1998). Rescue of Caenorhabditis elegans pharyngeal development by a vertebrate heart specification gene. Proc. Natl. Acad. Sci. USA 95: 5072-5075.

HOLLAND, N.D., VENKATESH, T.V., HOLLAND, L.Z., JACOBS, D.K., and BODMER, R. (2003) AmphiNk2-tin, an amphioxus homeobox gene expressed in myocardial progenitors: insights into evolution of the vertebrate heart. Dev. Biol. 255:128-37.

HOOGAARS, W.M., BARNETT, P., MOORMAN, A.F., CHRISTOFFELS, V.M (2007a). Cardiovascular development: towards biomedical applicability: T-box factors determine cardiac design. Cell. Mol. Life Sci. 64: 646-660.

HOOGAARS, W.M., ENGEL, A., BRONS, J.F., VERKERK, A.O., DE LANGE, F.J., WONG, L.Y., BAKKER, M.L., CLOUT, D.E., WAKKER, V., BARNETT, P., RAVESLOOT, J.H., MOORMAN, A.F., VERHEIJCK, E.E. and CHRISTOFFELS, V.M. (2007b). Tbx3 controls the sinoatrial node gene program and imposes pacemaker function on the atria. Genes Dev. 21: 1098-1112.

HUTSON, M.R., and KIRBY, M.L. (2007) Model systems for the study of heart development and disease. Cardiac neural crest and conotruncal malformations. Semin. Cell Dev. Biol. 18:101-110.

HUTSON, M.R., ZHANG, P., STADT, H.A., SATO, A.K., LI, Y.X., BURCH, J., CREAZZO, T.L., and KIRBY, M.L. (2006) Cardiac arterial pole alignment is sensitive to FGF8 signaling in the pharynx. Dev. Biol. 295:486-497.

JAMIESON, B.G.M. (1992) Oligochaeta. In: Microscopic Anatomy of Invertebrates (Eds. Harrison, F. W. and Gardiner, S. L.) Vol. 7, Annelida. Wiley-Liss, New York., pp. 217-322.

JIAO, K., LANGWORTHY, M., BATTS, L., BROWN, C.B., MOSES, H.L., and BALDWIN, H.S. (2006) Tgfbeta signaling is required for atrioventricular cushion mesenchyme remodeling during in vivo cardiac development. Development 133:4585-4593.

KATHIRIYA, I.S. and SRIVASTAVA, D. (2000). Left-right asymmetry and cardiac looping: implications for cardiac development and congenital heart disease. Am. J. Med. Genet. 97: 271-279.

KEEGAN, B.R., MEYER, D., and YELON, D. (2004). Organization of cardiac chamber progenitors in the zebrafish blastula. Development 131: 3081-3091.

KELLY, R.G., BROWN, N.A. and BUCKINGHAM, M.E. (2001). The arterial pole of the mouse heart forms from Fgf10-expressing cells in pharyngeal mesoderm. Dev. Cel/1: 435-440.

KELLY, R.G., FRANCO, D., MOORMAN, A.F. and BUCKINGHAM, M. (1999). Regionalization of transcriptional potential in the myocardium. In Heart Development (ed. R.P. Harvey and N. Rosenthal). Academic Press, San Diego, CA., pp. 333-355. 
KIRBY, M.L. (2002). Molecular embryogenesis of the heart. Ped. Dev. Pathol. 5: 516-543.

KIRBY, M.L. (2007). Cardiac development. Oxford University Press, New York., pp. 21-33.

KITAJIMA, S., TAKAGI, A., INOUE, T. and SAGA, Y. (2000). MesP1 and MesP2 are essential for the development of cardiac mesoderm. Development 127: 32152326.

KOLSCH, V. and PAULULAT, A. (2002). The highly conserved cardiogenic bHLH factor Hand is specifically expressed in circular visceral muscle progenitor cells and in all cell types of the dorsal vessel during Drosophila embryogenesis. Dev. Genes Evo/212: 473-485.

KURATA, S., GO, M.J., ARTAVANIS-TSAKONAS, S., and GEHRING, W.J. (2000) Notch signaling and the determination of appendage identity. Proc. Natl. Acad. Sci. USA 97:2117-2122.

KWON, C., HAN, Z., OLSON, E.N. and SRIVASTAVA, D. (2005). MicroRNA1 influences cardiac differentiation in Drosophila and regulates Notch signaling. Proc. Natl. Acad. Sci. USA 102: 18986-18991.

LAMERS, W.H., WESSELS, A., VERBEEK, F.J., MOORMAN, A.F., VIRAGH, S., WENINK, A.C., GITTENBERGER-DE GROOT, A.C. and ANDERSON, R.H. (1992). New findings concerning ventricular septation in the human heart. Implications for maldevelopment. Circulation 86: 1194-1205.

LAUGWITZ, K.L., MORETTI, A., LAM, J., GRUBER, P., CHEN, Y., WOODARD, S., LIN, L.Z., CAI, C.L., LU, M.M., RETH, M., PLATOSHYN, O., YUAN, J.X. EVANS, S. and CHIEN, K.R. (2005). Postnatal isl1+ cardioblasts enter fully differentiated cardiomyocyte lineages. Nature 433: 647-653.

LAVINE, k.j., YU, K., WHITE, A.C., ZHANG, X., SMITH, C., PARTANEN, J. and ORNITZ, D.M. (2005). Endocardial and epicardial derived FGF signals regulate myocardial proliferation and differentiation in vivo. Dev. Ce//8:85-95.

LEE, K.F., SIMON, H., CHEN, H., BATES, B., HUNG, M.C., and HAUSER, C. (1995). Requirement for neuregulin receptor erbB2 in neural and cardiac development. Nature 378: 394-398.

LI, Y.X., ZDANOWICZ, M., YOUNG, L., KUMISKI, D., LEATHERBURY, L., and KIRBY, M.L. (2003) Cardiac neural crest in zebrafish embryos contributes to myocardial cell lineage and early heart function. Dev. Dyn. 226:540-550.

LINASK, K.K. and LASH, J.W. (1993) Early heart development: dynamics of endocardial cell sorting suggests a common origin with cardiomyocites. Dev. Dyn. 195:62-69.

LIU, M., SU, M., LYONS, G.E., and BODMER, R. (2006) Functional conservation of zinc-finger homeodomain gene zfh1/SIP1 in Drosophila heart development. Dev. Genes Evol. 216:683-693.

LOUGH, J. and SUGI, Y. (1995). Activin-A and FGF-2 mimic the inductive effects of anterior endoderm on terminal cardiac myogenesis in vitro. Dev. Biol.168: 567-574.

LOUGH, J. and SUGI, Y. (2000). Endoderm and heart development. Dev. Dyn. 217: 327-342.

LOWE, C.J., TERASAKI, M., WU, M., FREEMAN, R.M. Jr, RUNFT, L., KWAN, K., HAIGO, S., ARONOWICZ, J., LANDER, E., GRUBER, C., SMITH, M., KIRSCHNER, M., and GERHART, J. (2006) Dorsoventral patterning in hemichordates: insights into early chordate evolution. PLOS Biol. 4:e291.

LOWE, L.A., SUPP, D.M., SAMPATH, K., YOKOYAMA, T., WRIGHT, C.V., POTTER, S.S., OVERBEEK, P., and KUEHN, M.R. (1996). Conserved left-right asymmetry of nodal expression and alterations in murine situs inversus. Nature 381: 158-161.

LYONS, G.E. (1994). In situ analysis of the cardiac muscle gene program during embryogenesis. Trends Cardiovasc. Med. 4: 70-77.

LYONS, G.E., SCHIAFFINO, S., SASSOON, D., BARTON, P. and BUCKINGHAM, M. (1990). Developmental regulation of myosin gene expression in mouse cardiac muscle. J. Cel/ Biol. 111: 2427-2436.

MANASEK, F.J. (1968). Embryonic development of the heart. I. A light and electron microscopic study of myocardial development in the early chick embryo. J. Morphol. 125: 329-365.

MÄNNER, J. (2000). Cardiac looping in the chick embryo: a morphological review with special reference to terminological and biomechanical aspects of the looping process. Anat. Rec. 259: 248-262.

MÄNNER, J., PÉREZ-POMARES, J.M., MACÍAS, D. and MUÑOZ-CHÁPULI, R.
(2001) The origin, formation, and developmental significance of the epicardium: a review. Cell Tiss. Org. 169:89-103.

MÄNNER, J., SEIDL, W. and STEDING, G. (1993). Correlation between the embryonic head flexures and cardiac development. An experimental study in chick embryos. Anat. Embryol. 188: 269-285.

MANNING, A., MCLACHLAN, J.C. (1990). Looping of chick embryo hearts in vitro. J. Anat. 168: 257-263.

MARTIN, G.G., and HOSE, J.E. (1992) Vascular elements and blood (hemolymph). In: Microscopic Anatomy of Invertebrates (Eds. Harrison, F.W. and Humes, A.G.). Vol. 10, Decapod Crustacea. Wiley-Liss, New York., pp. 117-146

MCMAHON, B.R. (2001) Control of cardiovascular function and its evolution in Crustacea. J. Exp. Biol. 204:923-932.

MEILHAC, S.M., ESNER, M., KELLY, R.G., NICOLAS, J.F. and BUCKINGHAM M.E. (2004). The clonal origin of myocardial cells in different regions of the embryonic mouse heart. Dev. Ce//6: 685-698.

MEYER, D. and BIRCHMEIER, C. (1995). Multiple essential functions of neuregulin in development. Nature 378: 386-390.

MIKAWA, T. and HURTADO, R. (2007). Development of the cardiac conduction system. Semin Cell Dev. Biol.18: 90-100.

MILLAR, R.H. (1953). Ciona. The University Press of Liverpool, Liverpool.

MISKOLCZI-MCCALLUM, C.M., SCAVETTA, R.J., SVENDSEN, P.C., SOANES K.H. and BROOK, W.J. (2005). The Drosophila melanogaster T-box genes midline and $\mathrm{H} 15$ are conserved regulators of heart development. Dev. Biol.278: 459-472.

MJAATVEDT, C.H., and MARKWALD, R.R. (1989) Induction of an epithelialmesenchymal transition by an in vivo adheron-like complex. Dev. Biol. 136:118 128.

MJAATVEDT, C.H., NAKAOKA, T., MORENO-RODRIGUEZ, R., NORRIS, R.A KERN, M.J., EISENBERG, C.A., TURNER, D. and MARKWALD, R.R. (2001). The outflow tract of the heart is recruited from a novel heart-forming field. Dev. Biol.238: 97-109.

MOMMERSTEEG, M.T., HOOGAARS, W.M., PRALL, O.W., DE GIER-DE VRIES, C., WIESE, C, CLOUT, D.E., PAPAIOANNOU, V.E., BROWN, N.A., HARVEY, R.P., MOORMAN, A.F. and CHRISTOFFELS, V.M. (2007). Molecular pathway for the localized formation of the sinoatrial node. Circ. Res. 100:354-362.

MOORE, A.W., BARBEL, S., JAN, L.Y., JAN, Y.N. (2000) A genomewide survey of basic helix-loop-helix factors in Drosophila. Proc. Natl. Acad. Sci. USA97:1043610441

MOORE, A.W., MCINNES, L., KREIDBERG, J., HASTIE, N.D. and SCHEDL, A (1999). YAC complementation shows a requirement for $W t 1$ in the development of epicardium, adrenal gland and throughout nephrogenesis. Development 126 : 1845-1857.

MOORE, A.W., SCHEDL, A., MCINNES, L., DOYLE, M., HECKSHER-SORENSEN J. and HASTIE, N.D. (1998) YAC transgenic analysis reveals Wilms' tumour 1 gene activity in the proliferating coelomic epithelium, developing diaphragm and limb. Mech. Dev. 79:169-184

MOORMAN, A.F. and CHRISTOFFELS. (2003). Cardiac chamber formation development, genes, and evolution. Physiol. Rev. 83: 1223-1267.

MOORMAN, A.F., CHRISTOFFELS, V.M. and ANDERSON, R.H. (2005).Anatomic substrates for cardiac conduction. Heart Rhythm 2: 875-886.

MOORMAN, A.F., CHRISTOFFELS, V.M., ANDERSON, R.H., and VAN DEN HOFF, M.J. (2007). The heart-forming fields: one or multiple? Philos. Trans. $R$ Soc. Lond. B Biol. Sci. 362: 1257-1265.

MOORMAN, A.F., DE JONG, F., DENYN, M.M. and LAMERS, W.H. (1998). Development of the cardiac conduction system. Circ. Res. 82: 629-644.

MOORMAN, A.F., SOUFAN, A.T., HAGOORT, J., DE BOER, P.A., and CHRISTOFFELS, V.M. (2004). Development of the building plan of the heart. Ann. N. Y. Acad. Sci. 1015: 171-181.

MORIMOTO, M., KISO, M. AND SAGA, Y. (2006). Cooperative Mesp activity is required for normal somitogenesis along the anterior-posterior axis. Dev. Biol. 300: 687-698.

MORRISON, S.J., PEREZ, S.E., QIAO, Z., VERDI, J.M., HICKS, C., WEINMASTER, G., and ANDERSON, D.J. (2000) Transient Notch activation initiates an irreversible switch from neurogenesis to gliogenesis by neural crest stem cells. Cell 101:499-510. 
MUÑOZ-CHÁPULI, R., CARMONA, R., GUADIX, J. A., MACÍAS, D., and PÉREZPOMARES, J. M. (2005). The origin of the endothelial cells: an evo-devo approach for the invertebrate/vertebrate transition of the circulatory system. Evol. Dev. 7:351-358.

NAICHE, L.A., HARRELSON, Z., KELLY, R.G. and PAPAIOANNOU, V.E. (2005). T-box genes in vertebrate development. Annu. Rev. Genet. 39: 219-239.

NAKAJIMA, Y., YAMAGISHI, T., NAKAMURA, H., MARKWALD, R.R., and KRUG, E.L. (1998). An autocrine function for transforming growth factor (TGF)-beta3 in the transformation of atrioventricular canal endocardium into mesenchyme during chick heart development. Dev. Biol. 194:99-113.

NEEDHAM, J. 1950. Biochemistry and Morphogenesis. Cambridge University Press, Cambridge.

O'BRIEN, T.X., LEE, K.J. and CHIEN, K.R. (1993). Positional specification of ventricular myosin light chain 2 expression in the primitive murine heart tube. Proc. Natl. Acad. Sci. USA 90: 5157-5161.

OKKEMA, P.G. and FIRE, A. (1994). The Caenorhabditis elegans NK-2 class homeoprotein $\mathrm{CEH}-22$ is involved in combinatorial activation of gene expression in pharyngeal muscle. Development 120: 2175-2186.

OLSON, E.N. (2006) Gene regulatory networks in the evolution and development of the heart. Science 313:1922-1927.

OOSTHOEK, P.W., VIRAGH, S., LAMERS, W.H. and MOORMAN, A.F. (1993a). Immunohistochemical delineation of the conduction system. II: The atrioventricular node and Purkinje fibers. Circ. Res. 73: 482-491.

OOSTHOEK, P.W., VIRAGH, S., MAYEN, A.E., VAN KEMPEN, M.J., LAMERS, W.H. and MOORMAN, A.F. (1993b). Immunohistochemical delineation of the conduction system. I: The sinoatrial node. Circ. Res. 73: 473-481.

PENG, I., DENNIS, J.E., RODRIGUEZ-BOULAN, E. AND FISCHMAN, D.A. (1990). Polarized release of enveloped viruses in the embryonic chick heart: demonstration of epithelial polarity in the presumptive myocardium. Dev. Biol.141: 164172.

PÉREZ-POMARES, J.M., PHELPS, A., SEDMEROVA, M., CARMONA, R., GONZÁLEZ-IRIARTE, M., MUÑOZ-CHÁPULI, R. and WESSELS, A. (2002). Experimental studies on the spatiotemporal expression of WT1 and RALDH2 in the embryonic avian heart: a model for the regulation of myocardial and valvuloseptal development by epicardially derived cells (EPDCs). Dev. Biol. 247: 307-326.

PÉREZ-POMARES, J.M., CARMONA, R., GUADIX, J.A., and MUÑOZ-CHÁPULI, R. (2006). In vivo and in vitro analysis of the vasculogenic potential of avian proepicardial and epicardial cells. Dev. Dyn. 235: 1014-1026.

POMBAL, M.A., CARMONA, R., MEGÍAS, M., RUIZ, A., PÉREZ-POMARES, J.M. and MUÑOZ-CHÁPULI, R. Epicardial development in lamprey supports an evolutionary origin of the vertebrate epicardium from an ancestral pronephric external glomerulus. Evol. Dev. (2008, in press).

POTTS, J.D., and RUNYAN, R.B. (1989) Epithelial-mesenchymal cell transformation in the embryonic heart can be mediated, in part, by transforming growth factor beta. Dev. Biol. 134:392-401.

PRALL, O.W., MENON, M.K., SOLLOWAY, M.J., WATANABE, Y., ZAFFRAN, S., BAJOLLE, F., BIBEN, C., MCBRIDE, J.J., ROBERTSON, B.R., CHAULET, H., STENNARD, F.A., WISE, N., SCHAFT, D., WOLSTEIN, O., FURTADO, M.B., SHIRATORI, H., CHIEN, K.R., HAMADA, H., BLACK, B.L, SAGA, Y., ROBERTSON, E.J., BUCKINGHAM, M.E. and HARVEY, R.P. (2007). An Nkx25/Bmp2/Smad1 negative feedback loop controls heart progenitor specification and proliferation. Cel/128: 947-959.

QIAN, L., LIU, J. and BODMER, R. (2005). Neuromancer Tbx20-related genes (H15/midline) promote cell fate specification and morphogenesis of the Drosophila heart. Dev. Biol. 279: 509-524.

QUAGGIN, S.E., SCHWARTZ, L., CUI, S., IGARASHI, P., DEIMLING, J., POST, M., ROSSANT, J. (1999) The basic-helix-loop-helix protein pod1 is critically important for kidney and lung organogenesis. Development 126:5771-5783.

RAMSDELL, A.F., and MARKWALD, R.R. (1997) Induction of endocardial cushion tissue in the avian heart is regulated, in part, by TGFbeta-3-mediated autocrine signaling. Dev. Biol. 188:64-74.

RANA, M.S., HORSTEN, N.C., TESINK-TAEKEMA, S., LAMERS, W.H., MOORMAN, A.F. and VAN DEN HOFF, M.J. (2007). Trabeculated right ventricular free wall in the chicken heart forms by ventricularization of the myocardium initially forming the outflow tract. Circ. Res. 100: 1000-1007.
REDKAR, A., MONTGOMERY, M., and LITVIN, J. (2001). Fate map of early avian cardiac progenitor cells. Development 128: 2269-2279.

REIM, I. and FRASCH, M. (2005). The Dorsocross T-box genes are key components of the regulatory network controlling early cardiogenesis in Drosophila. Development 132: 4911-4925.

REIM, I., MOHLER, J.P. and FRASCH, M. (2005). Tbx20-related genes, mid and $\mathrm{H} 15$, are required for tinman expression, proper patterning, and normal differentiation of cardioblasts in Drosophila. Mech. Dev. 122: 1056-1069.

ROMANO, L.A., and RUNYAN, R.B. (2000) Slug is an essential target of TGFbeta2 signaling in the developing chicken heart. Dev. Biol. 223:91-102.

ROSENQUIST, G.C. (1970). Location and movements of cardiogenic cells in the chick embryo: the heart-forming portion of the primitive streak. Dev. Biol. 22: 461-475.

RUNYAN, R.B., and MARKWALD, R.R. (1983) Invasion of mesenchyme into threedimensional collagen gels: a regional and temporal analysis of interaction in embryonic heart tissue. Dev. Biol. 95:108-114.

RUPPERT, E.E. (1991) Introduction to the Aschelminth phyla: A consideration of mesoderm, body cavities and cuticle. In: Microscopic Anatomy of Invertebrates (Eds. Harrison, F.W. and Ruppert, E.E.). Vol. 4, Aschelminthes. Wiley-Liss, New York., pp. 1-18.

RUPPERT, E.E. (1997) Cephalochordata (Acrania). In: Microscopic Anatomy of Invertebrates (Eds. Harrison, F.W. and Ruppert, E.E.). Vol. 15, Hemichordata, Chaethognatha and the invertebrate Chordates. Wiley-Liss, New York., pp. 349-504.

RUPPERT, E.E., and CARLE, K.J. (1983) Morphology of the metazoan circulatory systems. Zoomorphology, 103:193-208.

SAGA, Y., MIYAGAWA-TOMITA, S., TAKAGI, A., KITAJIMA, S., MIYAZAKI, J. and INOUE, T. (1999). MesP1 is expressed in the heart precursor cells and required for the formation of a single heart tube. Development 126: 3437-3447.

SATO, M., and YOST, H.J. (2003) Cardiac neural crest contributes to cardiomyogenesis in zebrafish. Dev. Biol. 257:127-139.

SATOU, Y., IMAI, K.S. and SATOH, N. (2004). The ascidian Mesp gene specifies heart precursor cells. Development 131: 2533-2541.

SCHOENEBECK, J.J, KEEGAN, B.R, and YELON, D. (2007). Vessel and blood specification override cardiac potential in anterior mesoderm. Dev. Cell. 13: 254-267.

SCHOENWOLF, G.C. and ALVAREZ, I.S. (1991). Specification of neuroepithelium and surface epithelium in avian transplantation chimeras. Development 112: 713-722.

SCHULTHEISS, T.M., XYDAS, S. and LASSAR, A.B. (1995). Induction of avian cardiac myogenesis by anterior endoderm. Development 121: 4203-4214.

SEDMERA, D., RECKOVA, M., DE ALMEIDA, A., COPPEN, S.R., KUBALAK, S.W., GOURDIE, R.G. and THOMPSON, R.P. (2003). Spatiotemporal pattern of commitment to slowed proliferation in the embryonic mouse heart indicates progressive differentiation of the cardiac conduction system. Anat. Rec. 274: 773-777.

SIMÕES-COSTA, M.S., VASCONCELOS, M., SAMPAIO, A.C., CRAVO, R.M., LINHARES, V.L., HOCHGREB, T., YAN, C.Y.I., DAVIDSON, B., and XAVIERNETO, J. (2005). The evolutionary origin of cardiac chambers. Dev. Biol. 277 1-15.

SMILEY, S. (1994) Holothurioidea. In: Microscopic Anatomy of Invertebrates (Eds. Harrison, F.W. and Chia, F.S.). Vol. 14, Echinodermata. Wiley-Liss, New York., pp. 401-472.

SOMI, S., KLEIN, A.T., HOUWELING, A.C., RUIJTER, J.M., BUFFING, A.A., MOORMAN, A.F. and VAN DEN HOFF, M.J. (2006). Atrial and ventricular myosin heavy-chain expression in the developing chicken heart: strengths and limitations of non-radioactive in situ hybridization. J. Histochem. Cytochem. 54: 649-664.

SOUFAN, A.T., VAN DEN BERG, G., RUIJTER, J.M., DE BOER, P.A., VAN DEN HOFF, M.J. and MOORMAN, A.F. (2006). Regionalized sequence of myocardial cell growth and proliferation characterizes early chamber formation. Circ. Res. 99: 545-552.

SRIVASTAVA, D. (1999). HAND proteins: molecular mediators of cardiac development and congenital heart disease. Trends Cardiovasc. Med. 9: 11-18.

SRIVASTAVA D. (2006) Genetic regulation of cardiogenesis and congenital heart 
disease. Annu. Rev. Pathol. 1:199-213.

SRIVASTAVA, D. and OLSON, E.N. (2000). A genetic blueprint for cardiac development. Nature 407: 221-226.

SRIVASTAVA, D., THOMAS, T., LIN, Q., KIRBY, M.L., BROWN, D. and OLSON, E.N. (1997). Regulation of cardiac mesodermal and neural crest development by the bHLH transcription factor, dHAND. Nat. Genet. 16: 154-160.

STALSBERG, H. (1970). Mechanism of dextral looping of the embryonicheart. Am. J. Cardiol. 25: 265-271.

STALSBERG, H. and DE HAAN, R.L. (1969). The precardiac areas and formation of the tubular heart in the chick embryo. Dev. Biol. 19: 128-159.

STEDING, G. and SEIDL, W. (1980). Contribution to the development of the heart. Part I: normal development. Thorac. Cardiovasc. Surg. 28: 386-409.

STUCKMANN, I., EVANS, S. and LASSAR, A.B. (2003). Erythropoietin and retinoic acid, secreted from the epicardium, are required for cardiac myocyte proliferation. Dev. Biol. 255: 334-349.

SUGI, Y. and MARKWALD, R.R. (1996). Formation and early morphogenesis of endocardial endothelial precursor cells and the role of endoderm. Dev. Biol.175: 66-83.

SUGI, Y., and MARKWALD, R.R. (1996) Formation and early morphogenesis of endothelial precursors cells and the role of endoderm. Dev. Biol. 175:66-83.

TABER, L.A. (1998). Mechanical aspects of cardiac development. Prog. Biophys. Mol. Biol. 69: 237-255.

TAKATORI, N., HOTTA, K., MOCHIZUKI, Y., SATOH, G., MITANI, Y., SATOH, N., SATOU, Y. and TAKAHASHI, H. (2004). T-box genes in the ascidian Ciona intestinalis: characterization of cDNAs and spatial expression. Dev. Dyn. 230: 743-753.

TAKEBAYASHI-SUZUKI, K., YANAGISAWA, M., GOURDIE, R.G., KANZAWA, N and MIKAWA, T. (2000). In vivo induction of cardiac Purkinje fiber differentiation by coexpression of preproendothelin-1 and endothelin converting enzyme-1. Development 127: 3523-3532.

TAM, P.L. and BEDDINGTON, R.S.P. (1987). The formation of mesodermal tissues in the mouse embryo during gastrulation and early organogenesis. Development 99: 109-126.

TAM, P.L. and BEDDINGTON, R.S.P. (1992). Establishment and organization of germ layers in the gastrulating mouse embryo. Ciba Found. Symp. 165: 27-49.

TAM, P.L. and SCHOENWOLF, G.C. (1999). Cardiac fate maps: lineage allocation, morphogenetic movement, and cell commitment. In Heart Development (ed. R.P. Harvey and N. Rosenthal). Academic Press, San Diego, CA., pp. 3-18.

TAM, P.L. and ZHOU, S.X. (1996). The allocation of epiblast cells to ectodermal and germ-line lineage is influenced by the position of the cells in the gastrulating embryo. Dev. Biol.178: 124-132.

THOMPSON, R.P., RECKOVA, M., DE ALMEIDA, A., BIGELOW, M.R., STANLEY, C.P., SPRUILL, J.B., TRUSK, T.T and SEDMERA, D. (2003). The oldest, toughest cells in the heart. Novartis Found. Symp. 250: 157-174.

TIMMERMAN, L. A., GREGO-BESSA, J., RAYA, A., BERTRÁN, E., PÉREZPOMARES, J. M., DIEZ, J., ARANDA, S., PALOMO, S., MCCORMICK, F., IZPISÚA-BELMONTE, J. C., and DE LA POMPA, J. L. (2004). Notch promotes epithelial-mesenchymal transition during cardiac development and oncogenic transformation. Genes Dev. 18:99-115.

TURBEVILLE, J. M. (1986) An ultrastructural analysis of coelomogenesis in the hoplonemertine Prosorhochmus americanus and the polychaete Magelonasp. J. Morph. 187:51-60.

VIRAGH, S. and CHALLICE, C.E. (1973). Origin and differentiation of cardiac muscle cells in the mouse. J. Ultrastruct. Res. 42: 1-24.
VON BOTH, I., SILVESTRI, C., ERDEMIR, T., LICKERT, H., WALLS, J.R. HENKELMAN, R.M., ROSSANT, J., HARVEY, R.P., ATTISANO, L. and WRANA, J.L. (2004). Foxh1 is essential for development of the anterior heart field. Dev. Cel/7: 331-345.

VORONOV, D.A., ALFORD, P.W., XU, G. and TABER, L.A. (2004). The role of mechanical forces in dextral rotation during cardiac looping in the chick embryo. Dev. Biol. 272: 339-350.

WALDO, K.L., HUTSON, M.R., WARD, C.C., ZDANOWICZ, M., STADT, H.A., KUMISKI, D., ABU-ISSA, R., and KIRBY, M.L. (2005) Secondary heart field contributes myocardium and smooth muscle to the arterial pole of the developing heart. Dev. Biol. 281:78-90.

WALDO, K.L., KUMISKI, D.H., WALLIS, K.T., STADT, H.A., HUTSON, M.R., PLATT, D.H., and KIRBY, M.L. (2001) Conotruncal myocardium arises from a secondary heart field. Development 128:3179-3188.

WALLACE, R.L., RICCI, C., and MELONE, G. (1996) A cladistic analysis of pseudocoelomate (aschelminth) morphology. Invert. Biol. 115: 104-112.

WANG, H.U., CHEN, Z.F. and ANDERSON, D.J. (1998). Molecular distinction and angiogenic interaction between embryonic arteries and veins revealed by ephrin-B2 and its receptor Eph-B4. Cel/93: 741-753.

WEISS, P. (1939). Principles of Development. Holt, New York.

WESSELS, A. and PÉREZ-POMARES, J.M. (2004). The epicardium and epicardially derived cells (EPDCs) as cardiac stem cells. Anat. Rec. 276: 43-57.

WESSELS, A., MARKMAN, M.W., VERMEULEN, J.L., ANDERSON, R.H., MOORMAN, A.F. and LAMERS, W.H. (1996). The development of the atrioventricular junction in the human heart. Circ. Res. 78: 110-117.

WESSELS, A., VERMEULEN, J.L., VERBEEK, F.J., VIRAGH, S., KALMAN, F., LAMERS, W.H. and MOORMAN, A.F. (1992). Spatial distribution of «tissuespecific" antigens in the developing human heart and skeletal muscle. III. An immunohistochemical analysis of the distribution of the neural tissue antigen G1N2 in the embryonic heart; implications for the development of the atrioventricular conduction system. Anat. Rec. 232: 97-111.

XAVIER-NETO, J., CASTRO, R.A., M., SAMPAIO, A.C., AZAMBUJA, A.P., CASTILLO, H.A., CRAVO, R.M., and SIMÕES-COSTA, M.S. (2007). The evolutionary origin of cardiac chambers. Cell Mol. Life Sci. 64: 719-734.

YOSHIOKA, H., MENO, C., KOSHIBA, K., SUGIHARA, M., ITOH, H., ISHIMARU, Y., INOUE, T., OHUCHI, H., SEMINA, E.V., MURRAY, J.C., HAMADA, H. and NOJI, S. (1998). Pitx2, a bicoid-type homeobox gene, is involved in a leftysignaling pathway in determination of left-right asymmetry. Ce//94: 299-305.

YUAN, S. and SCHOENWOLF, G.C. (2000). Islet-1 marks the early heart rudiments and is asymmetrically expressed during early rotation of the foregut in the chick embryo. Anat. Rec. 260: 204-207.

YUTZEY, K.E., RHEE, J.T. and BADER, D. (1994). Expression of the atrial-specific myosin heavy chain $\mathrm{AMHC1}$ and the establishment of anteroposterior polarity in the developing chicken heart. Development 120: 871-883

ZAFFRAN, S., and FRASCH, M. (2002) Early signals in cardiac development. Circ. Res. 91:457-469.

ZHAO, Y., RANSOM, J.F., LI, A., VEDANTHAM, V., VON DREHLE, M., MUTH A.N., TSUCHIHASHI, T., MCMANUS, M.T., SCHWARTZ, R.J., and SRIVASTAVA, D. (2007). Dysregulation of cardiogenesis, cardiac conduction, and cell cycle in mice lacking miRNA-1-2. Cel/129: 303-317.

ZHAO, Y., SAMAL, E., and SRIVASTAVA, D. (2005). Serum response factor regulates a muscle-specific microRNA that targets Hand2 during cardiogenesis. Nature 436: 214-230.

ZHAO, Y., and SRIVASTAVA, D. (2007). A developmental view of microRNA function. Trends Biochem. Sci. 32: 189-197. 


\section{Further Related Reading, published previously in the Int. J. Dev. Biol.}

See our Special Issue Evolution \& Development edited by Jaume Baguñà and Jordi García-Fernández at:

http://www.ijdb.ehu.es/web/contents.php?vol=47\&issue=7-8

See our recent Special Issue Fertilization, in honor of David L. Garbers and edited by Paul M. Wassarman and Victor D. Vacquier at: http://www.ijdb.ehu.es/web/contents.php?vol=52\&issue=5-6

In vivo forced expression of myocardin in ventricular myocardium transiently impairs systolic performance in early neonatal pig heart

Mario Torrado, Alberto Centeno, Eduardo López and Alexander T. Mikhailov

Int. J. Dev. Biol. (2009) 53: 1457-1467 (doi: 10.1387/ijdb.072366mt)

Heart formation and left-right asymmetry in separated right and left embryos of a newt

Kazuhiro Takano, Yuzuru Ito, Shuichi Obata, Tsutomu Oinuma, Shinji Komazaki, Hiroaki Nakamura and Makoto Asashima Int. J. Dev. Biol. (2007) 51: 265-272

Amphibian in vitro heart induction: a simple and reliable model for the study of vertebrate cardiac development.

Takashi Ariizumi, Masayoshi Kinoshita, Chika Yokota, Kazuhiro Takano, Keiichi Fukuda, Nobuo Moriyama, George M Malacinski and Makoto Asashima

Int. J. Dev. Biol. (2003) 47: 405-410

Heat shock factor $\mathbf{2}$ is activated during mouse heart development.

M Eriksson, E Jokinen, L Sistonen and S Leppä

Int. J. Dev. Biol. (2000) 44: 471-477

Amphibian embryos as a model system for organ engineering: in vitro induction and rescue of the heart anlage.

H Grunz

Int. J. Dev. Biol. (1999) 43: 361-364

Heart development and regeneration in urodeles.

A W Neff, A E Dent and J B Armstrong

Int. J. Dev. Biol. (1996) 40: 719-725

Overexpression of the Xenopus XI-fli gene during early embryogenesis leads to anomalies in head and heart development and erythroid differentiation.

P Remy, F Sénan, D Meyer, A M Mager and C Hindelang

Int. J. Dev. Biol. (1996) 40: 577-589

Differentiation of myoendocrine cardiac cells from presumptive heart mesoderm explants of Bufo arenarum.

G C Ruiz, A Pisanó and D A Paz

Int. J. Dev. Biol. (1995) 39: 1033-109

Immunofluorescent confocal analysis of tropomyosin in developing hearts of normal and cardiac mutant axolotls, Ambystoma mexicanum.

$S$ La France and L F Lemanski

Int. J. Dev. Biol. (1994) 38: 695-700

Differentiation of endocrine myocardiocytes in the developing heart of the toad (Bufo arenarum Hensel).

V H Casco, D Paz, G Ruiz, C Maldonado, A Pisano and A Aoki

Int. J. Dev. Biol. (1992) 36: 537-542

Lack of proportionality between gene dosage and total muscle protein content in the rat heart.

V Y Brodsky, V Pelouch, A M Arefyeva, M Milerova and B Ostadal

Int. J. Dev. Biol. (1992) 36: 339-342

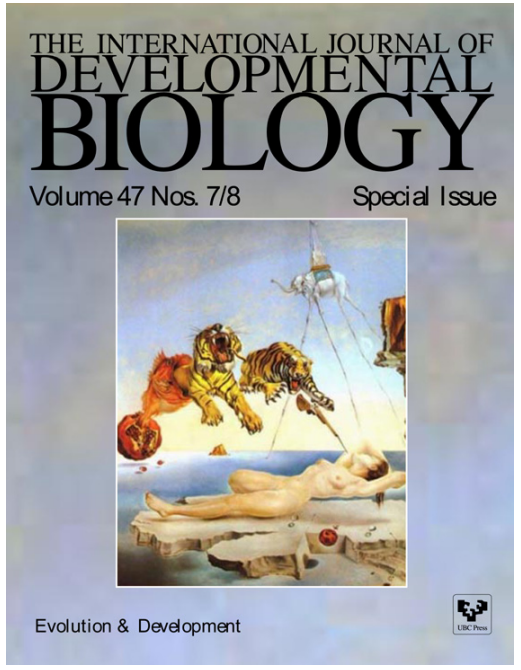

5 yr ISI Impact Factor $(2008)=3.271$

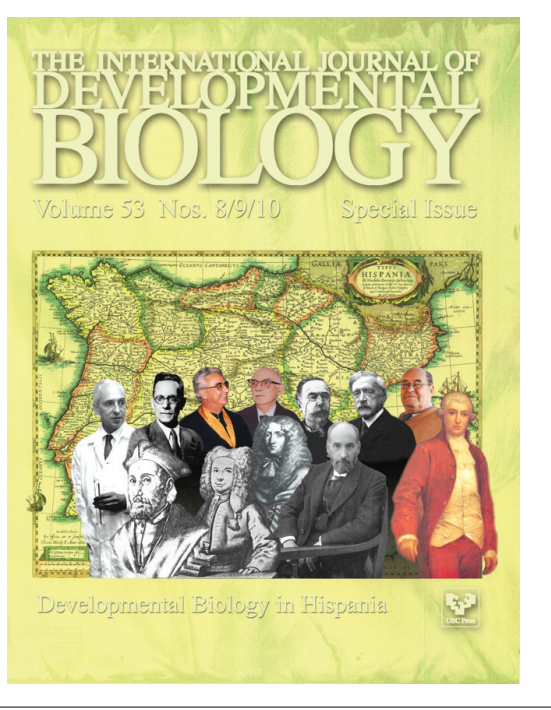

